\title{
Formation of atoll garnets in the UHP eclogites of the Tso Morari Complex, Ladakh, Himalaya
}

\author{
Mallika K Jonnalagadda ${ }^{1}$, Nitin R Karmalkar ${ }^{1,2, *}$, Raymond A Duraiswami ${ }^{1}$, \\ Shivani Harshe ${ }^{1}$, Sarah Gain ${ }^{2}$ and William L Griffin ${ }^{2}$ \\ ${ }^{1}$ Department of Geology, Savitribai Phule Pune University, Pune 411 00\%, India. \\ ${ }^{2}$ ARC Centre of Excellence for Core to Crust Fluid Systems and GEMOC, Department of Earth and Planetary \\ Sciences, Macquarie University, Sydney, NSW 2109, Australia. \\ *Corresponding author.e-mail: nrkarmal@unipune.ac.in; nrkarmalkar@gmail.com
}

MS received 9 August 2016; revised 24 May 2017; accepted 25 May 2017; published online 22 November 2017

The eclogites of the Tso Morari Complex, Ladakh, NW Himalayas preserve both garnets with spectacular atoll textures, as well as whole porphyroblastic garnets. Whole garnets are euhedral, idiomorphic and enclose inclusions of amphibole, phengite and zoisite within the cores, and omphacite and quartz/coesite towards the rims. Detailed electron microprobe analyses and back-scattered electron images show wellpreserved prograde zoning in the whole garnets with an increase in $\mathrm{Mg}$ and decrease in $\mathrm{Ca}$ and Mn contents from the core to the rim. The atoll garnets commonly consist of euhedral ring over island/peninsular core containing inclusions of phengite, omphacite and rarely amphibole between the core and ring. Compositional profiles across the studied atoll grains show elemental variations with higher concentrations of $\mathrm{Ca}$ and $\mathrm{Mn}$ with low $\mathrm{Mg}$ at the peninsula/island cores; contrary to this low $\mathrm{Ca}, \mathrm{Mn}$ and high $\mathrm{Mg}$ is observed at the outer rings. Temperature estimates yield higher values at the $\mathrm{Mg}$-rich atoll garnet outer rings compared to the atoll cores. Atoll garnet formation was favoured by infiltration of fluid formed due to breakdown of hydrous phases, and/or the release of structurally bounded $\mathrm{OH}$ from nominally anhydrous minerals at the onset of exhumation. Infiltration of fluids along pre-existing fracture pathways and along mineral inclusion boundaries triggered breakdown of the original garnet cores and released elements which were subsequently incorporated into the newly-grown garnet rings. This breakdown of garnet cores and inward re-growth at the outer ring produced the atoll structure. Calibrated geo-thermobarometers and mineral equilibria reflect that the Tso Morari eclogites attain peak pressures prior to peak temperatures representing a clockwise path of evolution.

Keywords. Atoll garnet; eclogite; fluid infiltration; retrograde metamorphism; Ladakh Himalayas; Tso Morari Complex.

\section{Introduction}

The occurrence of medium-temperature eclogites is a distinctive feature of many continental collision zones (Smith 1988; Carswell 1990). Garnet, one of the key mineral phases of eclogites, is crucial in deciphering the chemical and metamorphic evolution of these rocks during subduction. Garnetbearing rocks are most suitable for determining the duration and timing of mineral growth during metamorphism, and hence to understand the evolution of metamorphic belts. This is possible due 
to the slow rates of intra-crystalline diffusion and the complex compositional zoning patterns that are produced and retained in the garnet crystal structure over a wide range of metamorphic conditions (e.g., Spear and Selverstone 1983; Kohn and Spear 2000; Kohn 2003). Chemically zoned garnets can be used to constrain $\mathrm{P}-\mathrm{T}$ changes during tectono-metamorphic events. Garnet textures are primarily fingerprints of the history of nucleation and growth over a wide range of metamorphic conditions and can record both subduction (prograde metamorphism) and exhumation (retrograde metamorphism) histories. Metamorphic garnets may display several microstructures such as corona, symplectite, fishnet, atoll and patchy growth fabrics, in addition to normal monocrystalline grains. Major-element zoning patterns in garnets, during both prograde and retrograde metamorphism, have proved useful not only in understanding the $\mathrm{P}-\mathrm{T}$ evolution of metamorphic rocks but also in elucidating the evolution of metamorphic fluids and deformation patterns (Hollister 1966; Loomis 1975; Lasaga 1983; Spear and Selverstone 1983; Hickmott et al. 1987; Menard and Spear 1993; Perchuk et al. 1999; Faryad and Hoinkes 2004). The distinct growth patterns preserved in garnets are often separated by strong compositional gradients and/or inclusion-enriched zones that indicate episodic garnet growth during prograde metamorphism (Konrad-Schmolke et al. 2008). Atoll structure is a special type of microstructure consisting of a garnet ring enclosing a mixture of several phases and/or island-shaped garnet cores (Passchier and Trouw 1998). Several occurrences of atoll-structured garnets have been reported from eclogites in different ultra high pressure (UHP) belts across the world, e.g., Dabie, China (Cheng et al. 2007), Krušné Hory, Czech (Faryad et al. 2010), Alpujárride Complex, Spain, (Ruiz Cruz 2011) and Yukahe, China (Chen et al. 2011). Garnets displaying atoll textures have been reported previously from the Tso Morari massif (Singh et al. 2013; Kayleigh et al. 2014) in the Himalayas, but without deciphering the process of their formation. Several mechanisms of formation have been proposed for these structures, such as overgrowth (Smellie 1974); selective replacement (Green 1915; Williamson 1935; Rast 1965; Forestier and Lasnier 1969), multiple nucleation and coalescence of grains (Spiess et al. 2001; Dobbs et al. 2003), etc., but the mechanism of formation of atoll structures in lowto medium-grade metamorphic rocks is still in the realm of speculation. In the present work, detailed compositional maps along with line profiles and back-scattered electron images of whole garnets and atoll garnets of the Tso Morari UHP eclogites are reported for the first time. Applying conventional geothermobarometry, the $\mathrm{P}-\mathrm{T}$ path for the studied samples has been constrained. The present contribution therefore attempts to unravel the mechanism and processes leading to their formation in relation to changing $\mathrm{P}-\mathrm{T}$ conditions and their implications in understanding the tectonic models of UHP metamorphism.

\section{Geological setting and samples}

Discovery of coesite-bearing rocks in the Tso Morari Complex, India (Mukherjee and Sachan 2001; Sachan et al. 2001, 2004) and the Kaghan Valley, Pakistan (O'Brien et al. 2001) have established the presence of a UHP belt in the Himalayas. The eclogites under investigation form a part of the Tso Morari complex (TMC) located in the Ladakh region, NW Himalayas (figure 1a). The complex is an elongated, dome-shaped structure $100 \times 50 \mathrm{~km}$ across, and strikes NW-SE (Thakur 1983). The complex occurs as a doubly plunging anticline with a dip of $10^{\circ}$ towards the NW and an overall thickness of $<7 \mathrm{~km}$ (de Sigoyer et al. 2004). The Tso Morari unit is separated from the surrounding rocks by ductile shear zones. The TMC is tectonically bounded along its entire northern edge by the Indus suture zone. The north-east dipping Zildat shear zone delimits the Tso Morari unit from the low-grade metamorphic rocks of the Indus suture zone. The south dipping Karzog shear zone separates the dome from the less metamorphosed Mata-Karzog unit, and the Karzog and related ophiolites at its southwestern margin (Berthelsen 1953; Guillot et al. 1997; de Sigoyer et al. 2004; Mahéo et al. 2004; Epard and Steck 2008). The Puga Formation makes up the core of the complex, while the Tanglang La Formation lies towards the periphery. The complex is dominated by gneisses and schists (Puga Formation) along with phyllites, carbonates (Tanglang La Formation) and intrusive granitic bodies (Rupshu and Polokong La).

Traditionally, two existing models explain the metamorphic association of eclogites with its gneissic host. The 'foreign' model favours solid-state tectonic introduction of previously metamorphosed high-pressure eclogites into the lower-pressure gneissic host (Lappin and Smith 1978; Smith 1980, 1981, 1982). The second model favours the 


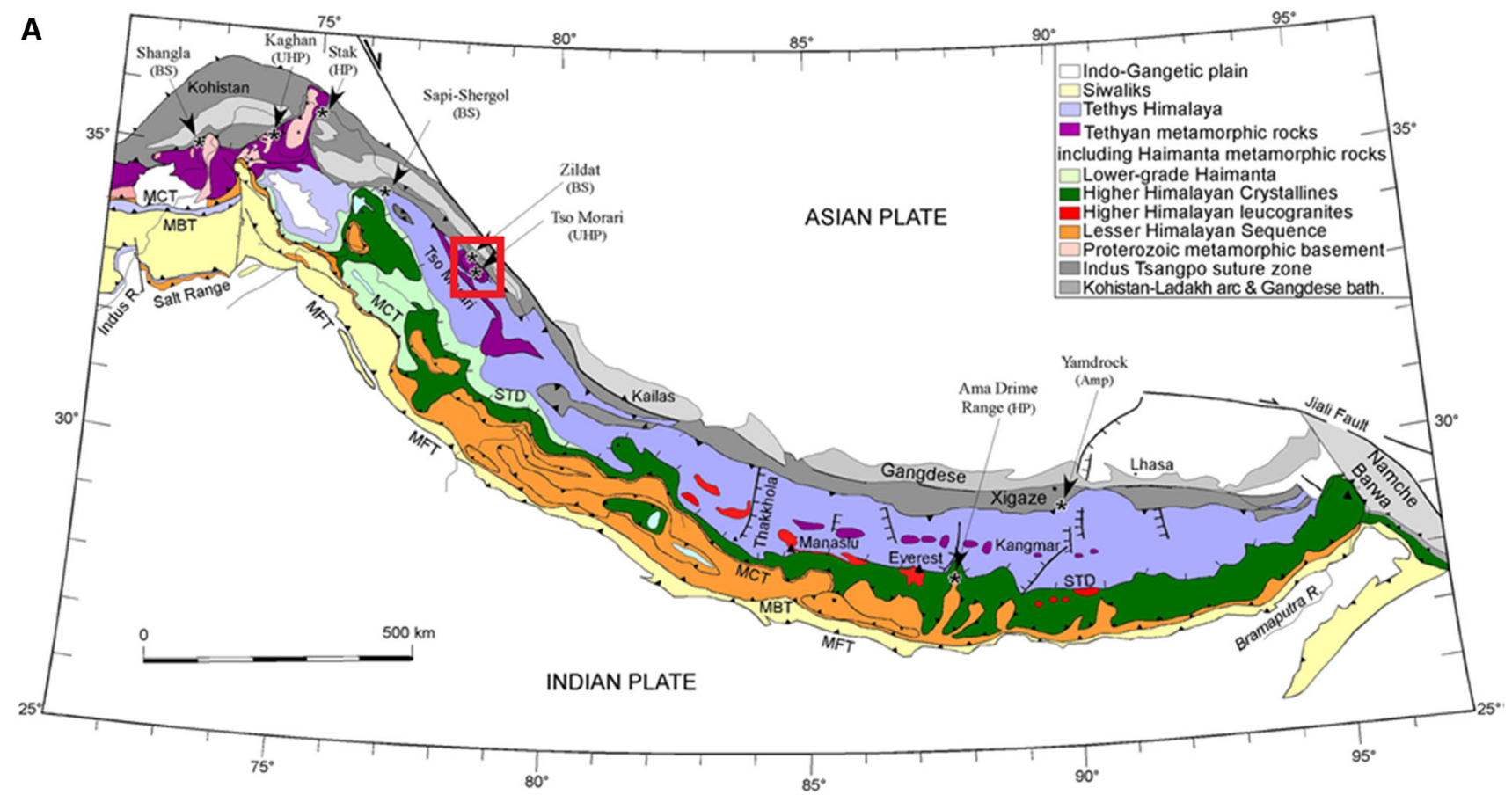

$32^{\circ} 25^{\prime} \mathrm{N} \quad 32^{\circ} 25^{\prime} \mathrm{N}$

B

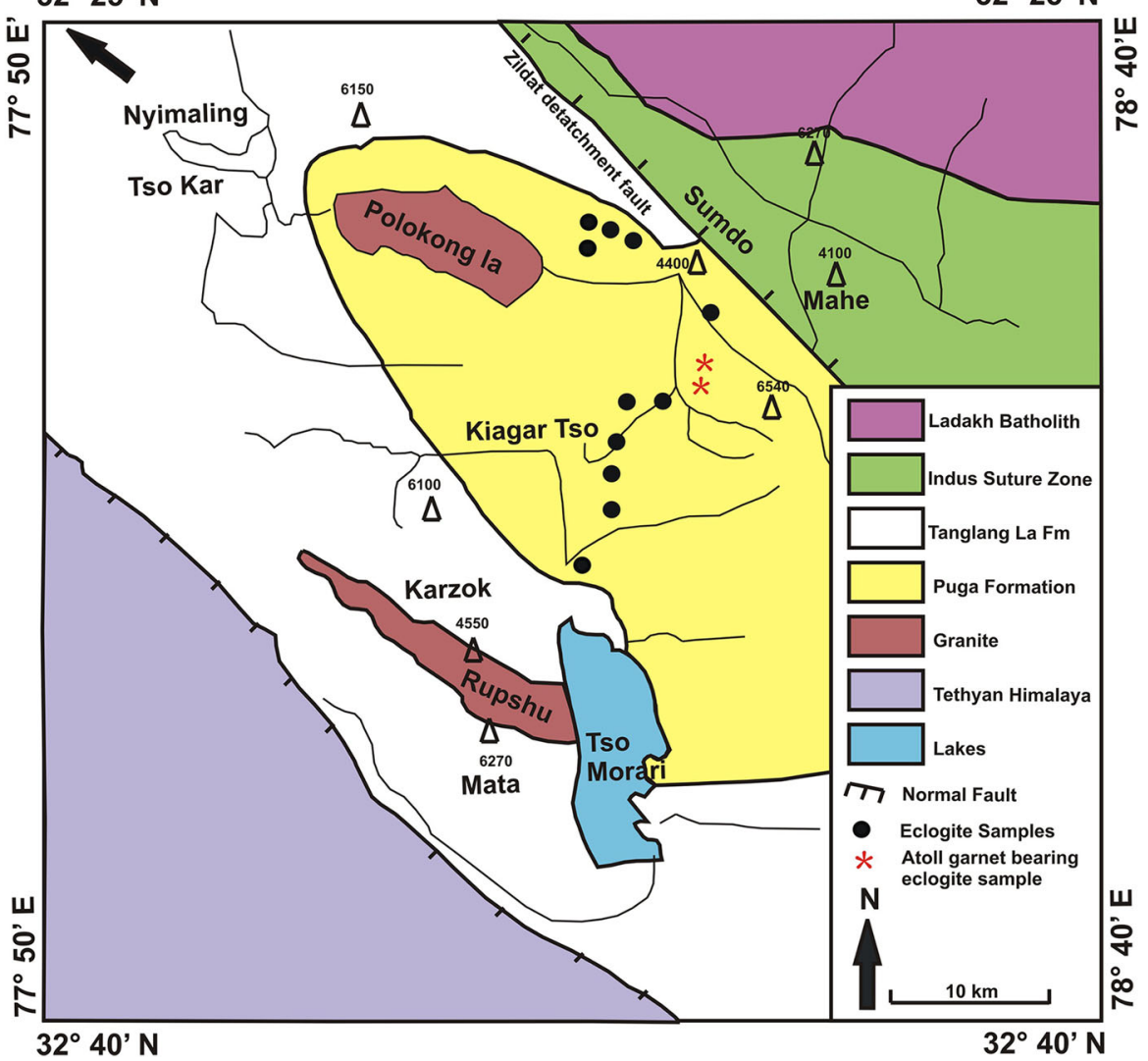

Figure 1. (a) Geological map of the Himalayas (after Ding et al. 2001; Guillot et al. 2003; Di Pietro et al. 2004). The western Himalayas are clearly distinct from the central-east Himalaya. The stars show the locations of the metamorphic rocks related to subduction processes. Inset, the red box shows the location of the study area. BS: Blueschist unit, Amp: amphibolitic unit; HP: high-pressure unit, UHP: ultrahigh-pressure unit (adapted from Guillot et al. 2008). (b) Geological map of the Tso Morari Complex (after Steck et al. 1998). Black dots represent eclogite sampling locations. Red dot shows the location of the atoll garnet eclogite sample. 
co-genetic metamorphism of the pre-existing mafic crustal rocks along with the gnessic host at the same $\mathrm{P}-\mathrm{T}$ conditions and thereby at the same subcrustal depths (Griffin and Brueckner 1980; Griffin and Carswell 1985; Griffin and Qvakem 1985).

The TMC is believed to represent a distal remnant block of the thinned northern Indian continental margin (Colchen et al. 1994; Steck et al. 1998). The area has been the focus of many recent investigations (de Sigoyer et al. 1997, 2000, 2004; Guillot et al. 1997; Jain et al. 2003; Leech et al. 2003, 2005; Epard and Steck 2008; Mukherjee and Mulchrone 2012; Lanari et al. 2013; St-Onge et al. 2013; Singh et al. 2013; Palin et al. 2014, 2017; Chatterjee and Jagoutz 2015; Wilke et al. 2015), primarily aimed at understanding the mechanisms of continental plate subduction and its exhumation during the collision of the Indian and Asian plates. These rocks are believed to have been exhumed through a low-viscosity channel along the top surface of the subducting slab (Guillot et al. 2001) although details of the exhumation mechanisms are poorly known. The eclogite samples for the present study were collected from the Puga Formation and the sampling locations are marked on figure 1(b). Eclogite bodies occur as boudins or lenses within the meta-sediments of the lower Puga and overlying Tanglang La Formations. The eclogites are marginally sheared, and exhibit a concordant relationship and sharp contacts with the host rocks (figure 2). Studies of these eclogites by de Sigoyer et al. (1997), Guillot et al. (1997) and Sachan et al. (1999) have recognized three metamorphic stages, viz., eclogitefacies assemblages, blueschist-facies assemblages and greenschist-facies assemblages, while Singh et al. (2013) have identified five different mineral associations representative of five stages of $\mathrm{P}-\mathrm{T}$ evolution of these rocks. $\mathrm{P}-\mathrm{T}$ estimates using mineral thermometers (garnet-clinopyroxene $\mathrm{Fe}-$ $\mathrm{Mg}$ exchange) and barometers ( $\mathrm{Si}$ in phengite, Jd in omphacite; de Sigoyer et al. 1997) suggest that the eclogitic garnet cores and rims equilibrated at pressures of $2.0 \pm 0.3$ and $1.1 \pm 0.2$ $\mathrm{GPa}$, respectively, at a constant temperature of $580 \pm 60^{\circ} \mathrm{C}$, suggesting isothermal decompression. St-Onge et al. (2013) used P-T pseudosection analysis to conclude that the eclogitic garnet cores and rims equilibrated at $2.15 \pm 0.15 \mathrm{GPa} / 535 \pm$ $15^{\circ} \mathrm{C}$ and $\sim 2.7 \mathrm{GPa} / 630-645^{\circ} \mathrm{C}$, respectively, indicating a $\mathrm{P}-\mathrm{T}$ increase during the growth of the garnet rims. Thermobarometric calculations by St-Onge et al. (2013) also suggest that the garnet

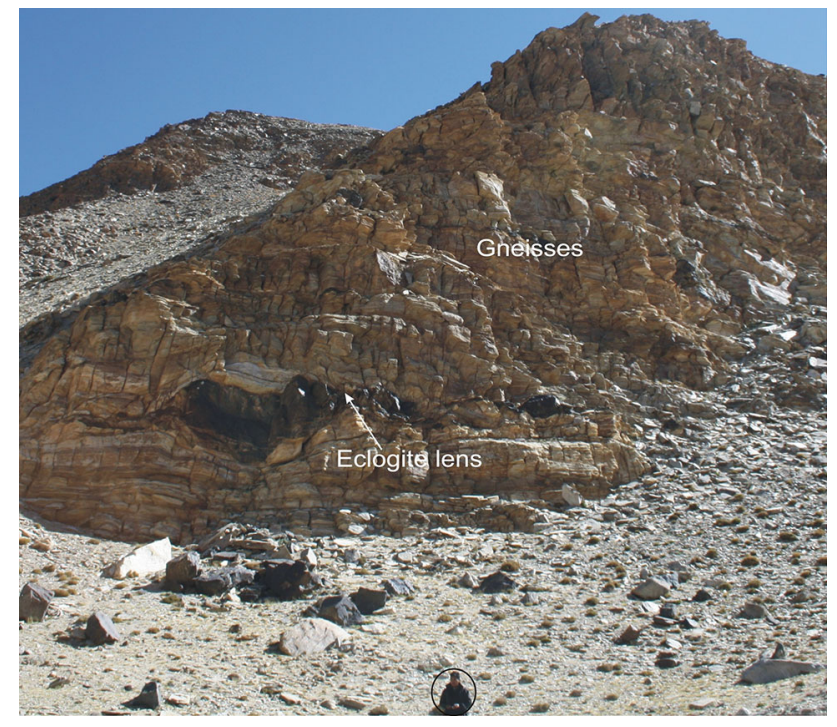

Figure 2. Field photographs of the Tso Morari eclogites. Eclogite bodies occuring as black mafic lenses or boudins observed within the Puga gneisses. Note the man circled for scale.

rims equilibrated at conditions of $\sim 2.55 \mathrm{GPa} /$ $602-617^{\circ} \mathrm{C}$. The report of coesite inclusions in the garnets (Mukherjee and Sachan 2001; Sachan et al. 2001, 2004) however, redefined the minimum pressure of $2.8 \mathrm{GPa}$ at $650^{\circ} \mathrm{C}$ for these rocks. Carbonate-bearing assemblages reported from the TMC suggest conditions of $\sim 3.9 \mathrm{GPa}$ at $\sim 750^{\circ} \mathrm{C}$ for the complex (Mukherjee et al. 2003). Whole rock and mineral isotopic ages of the Tso Morari eclogites (47-55 Ma, de Sigoyer et al. 2000; Leech et al. 2005; St-Onge et al. 2013; Donaldson et al. 2013) are consistent with the U-Pb zircon, allanite, and titanite ages of the Kaghan eclogites (44-50 Ma, Kaneko et al. 2003; Parrish et al. 2006; Wilke et al. 2010).

\section{Analytical methods}

Back-scattered electron (BSE) images, elemental $\mathrm{X}$-ray maps, and chemical compositions of minerals were obtained on an automated CAMECA SX100 electron microprobe micro-analyzer fitted with five crystal spectrometers at GEMOC, Macquarie University, Sydney, Australia. The minerals were analyzed by wave-length dispersive spectrometry (WDS) using an accelerating potential of $15 \mathrm{kV}$ and a probe current of $20 \mathrm{nA}$ and counting 40 $60 \mathrm{~s}$ times per element. The analyses were carried out with an effective beam diameter of $\sim 1$ micron. Standards used for the analysis were: jadeite for $\mathrm{Na}$, kyanite for $\mathrm{Al}$, olivine for $\mathrm{Mg}$, orthoclase 
for $\mathrm{K}$, wollastonite for $\mathrm{Ca}$ andradite for $\mathrm{Si}$, apatite for $\mathrm{P}, \mathrm{Cr}=\mathrm{Cr} 100 \%$, Mn garnet for $\mathrm{Mn}, \mathrm{Fe}_{2} \mathrm{O}_{3}$ on $\mathrm{Fe}, \mathrm{Ti}$ on $\mathrm{TiO}_{2}$, Ni for Ni-olivine. Representative analyses for whole and atoll garnets are shown in table 1 and all analyses are plotted in figure 3 .

\section{Petrography and mineral chemistry}

Two representative eclogite samples containing whole and atoll garnets respectively from the centre of the dome hosted within the orthognessies $\sim 5 \mathrm{~km}$ from the Sumdo village were subjected to detailed study. Macroscopically, the eclogites are very fresh and exhibit a fine-grained matrix composed of green omphacite and reddish garnet porphyroblasts. Microscopically, the samples contain predominantly garnets and omphacite porphyroblasts (figure 4a) surrounded by amphiboles (Na-Ca and Ca types), phengite, epidote and carbonates. Quartz/coesite are observed as minor constituents along with rutile, zircon, and oxides (Fe and $\mathrm{Ti}$ ) representing the accessory phases (figure 4c).

\subsection{Sample L1}

Garnets occur as large, idioblastic, whole porphyroblasts, $0.5-1.5 \mathrm{~mm}$ in size and exhibit intense optical zoning from reddish core to pale mantle and rims (figure 4a). Optical zoning is reflected in a wide compositional range, i.e., of almandine, pyrope, grossular and spessartine. Garnet cores are distinctly rich in $\mathrm{Ca}-\mathrm{Fe}\left(\mathrm{Grs}_{28-29} \mathrm{Alm}_{55-59}\right.$ $\left.\operatorname{Prp}_{11-14} \mathrm{Sps}_{1.7-1.9}\right)$ surrounded by thick Mg-rich rims $\left(\mathrm{Grs}_{17-19} \mathrm{Alm}_{60-66} \operatorname{Prp}_{24-26} \mathrm{Sps}_{0.8-0.6}\right)$. The grossular content decreases and the pyrope content increases sharply from the core to the rim. Garnet cores contain numerous inclusions with the rims being relatively free of inclusions. Common inclusions within the garnet cores consist of bluishgreen amphiboles, phengite and epidote (zoisite) (figure $4 \mathrm{~b}$ ), while the rim shows the presence of pale-coloured omphacite and rutile.

Inclusions of bluish-green coloured amphiboles within the whole garnet cores are $\mathrm{Na}-\mathrm{Ca}-$ amphiboles represented by ferro-kataphorite, kataphorite and taramite $[\mathrm{Na}(+\mathrm{K})=0.50-0.89$, $\mathrm{Na}(\mathrm{B})=0.51-0.69, \mathrm{Na}(\mathrm{A})=0.45-0.83$, total $\mathrm{Ca}=1.23-1.42, \mathrm{Al}^{i v}=0.94-2.03$ and $\mathrm{Al}^{v i}=$ $0.96-1.58)]$. Amphiboles found within the garnet rims are represented by ferro-pargasite, while matrix amphiboles and those rimming garnets are represented by winchite. Na-rich amphiboles occurring as inclusions within the garnet as reported by Singh et al. (2013) were not found in the present study.

Clinopyroxene inclusions occurring in garnet rims are primarily of omphacite $\left(\mathrm{Jd}_{35-40}, \mathrm{Ae}_{13-15}\right)$ which also occur in the matrix $\left(\mathrm{Jd}_{34-39}, \mathrm{Ae}_{14-18}\right)$. These grains are colourless to pale green and display feeble pleochroism in shades of light green. Omphacites are strongly zoned with $\mathrm{Jd}$ and $\mathrm{Ae}$ rich $\left(\mathrm{Jd}_{35-42} \mathrm{Ae}_{13-17}\right)$ cores where the rims are relatively lower in $\mathrm{Jd}$ and Ae contents $\left(\mathrm{Jd}_{35-40} \mathrm{Ae}_{13-14}\right)$ (figure 4f).

Coesite inclusions have also been observed in the garnet rims of the studied samples, consistent with earlier reports by Sachan et al. (2004). Most of the grains have a central core of fine-grained polycrystalline quartz with a radial rim of quartz defining the palisade texture. Coesite/quartz inclusions are surrounded by relaxation cracks, reflecting volume increase during the coesite to quartz transformation (figure 5). Trails of fluid inclusions of various shapes, viz., oblong, ovoid, amoeboid, etc., have been identified in the studied samples and occur within garnet, omphacite, phengite and at times in carbonate grains (figure 6). At places, fluid inclusions are also seen within the zircon and quartz grains. Mukherjee and Sachan (2009) have already identified five major types of fluids, viz., high-salinity brine, $\mathrm{N}_{2}, \mathrm{CH}_{4}, \mathrm{CO}_{2}$ and low-salinity aqueous fluids from these eclogites.

Retrograde assemblages consist of a symplectic intergrowth of possibly clinopyroxene + albite after omphacite (figure 4d); such replacement is very common in eclogites with omphacite that are more severely retrograded than garnet. Most symplectites coarsen away from the omphacite core, indicating that the symplectic aggregates in the outer rim might have formed early with longer recrystallization time.

Matrix omphacite grains exhibit exsolution lamellae which are identified to be of feldspar and minor quartz. Other retrograde features related to amphibolites and greenschist facies metamorphism include: (1) matrix rutile rimmed by titanite; (2) fibrous biotite formed at the expense of phengite (figure 4e); (3) chlorite formed after biotite and garnet; (4) quartz pseudomorphs after coesite in garnet; and (5) phengite inside the atoll is low-Si accompanied by quartz. The matrix here is dominated by $\mathrm{Ca}$ amphibole, feldspar and biotite. 


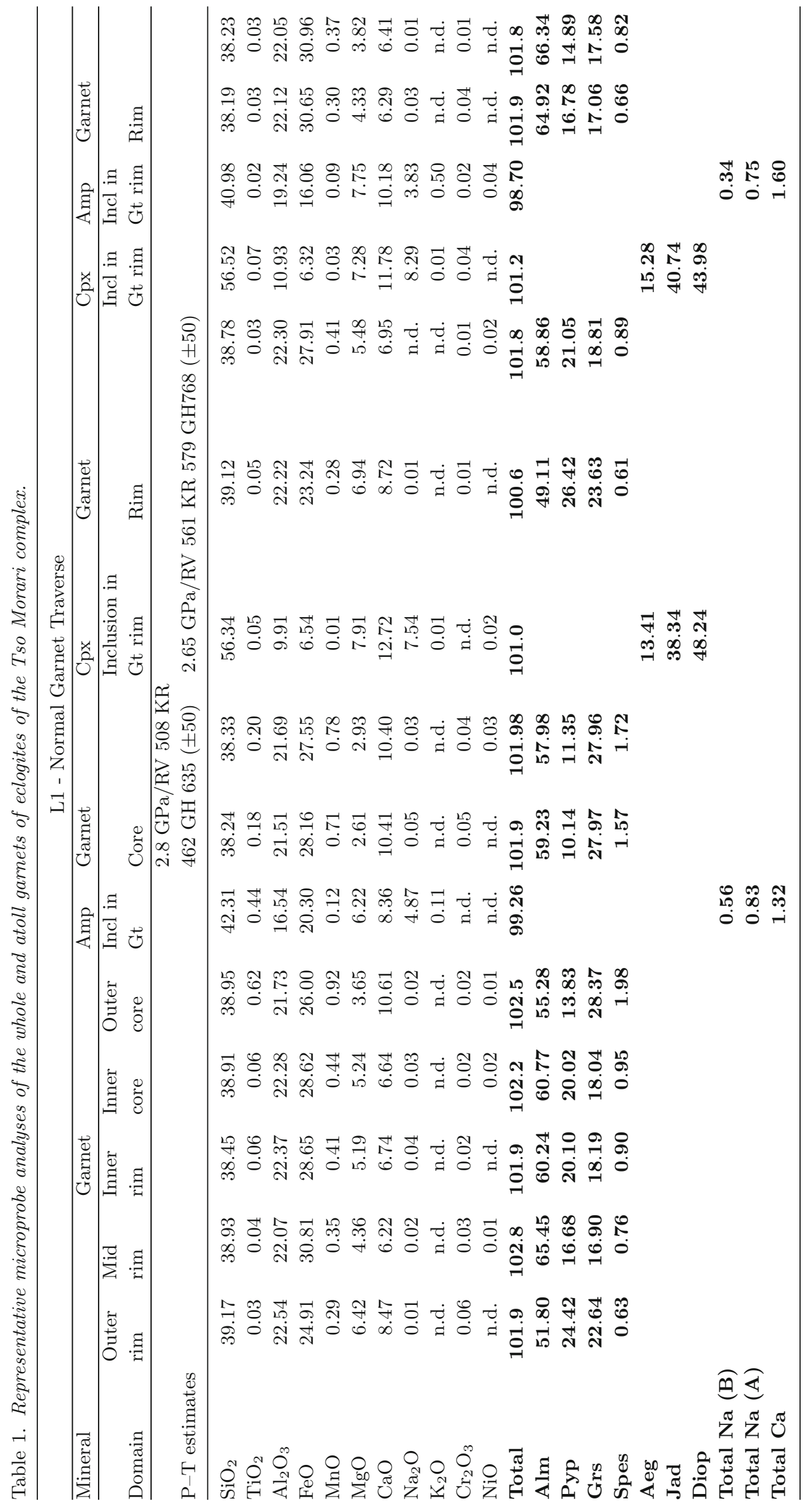




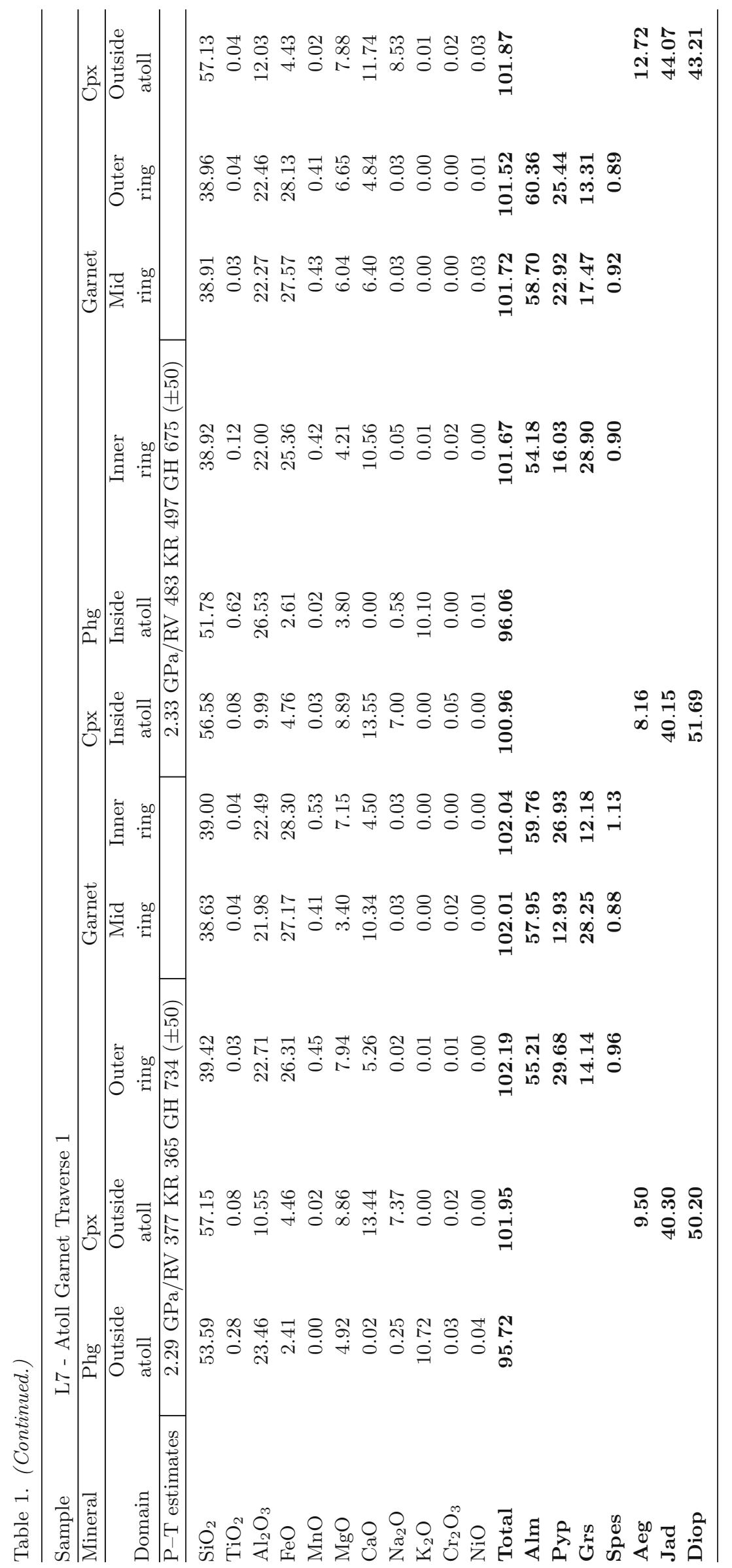




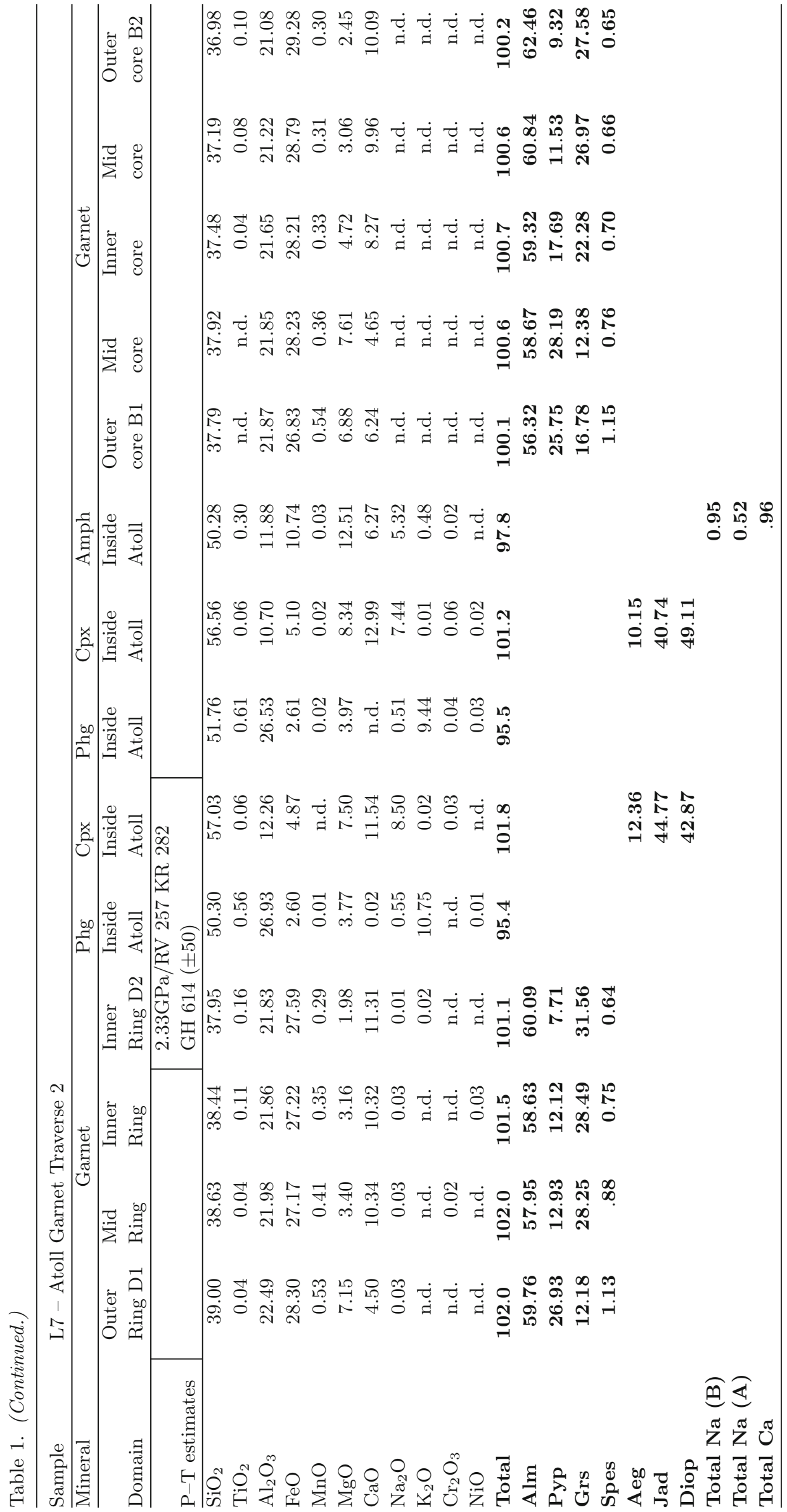


a

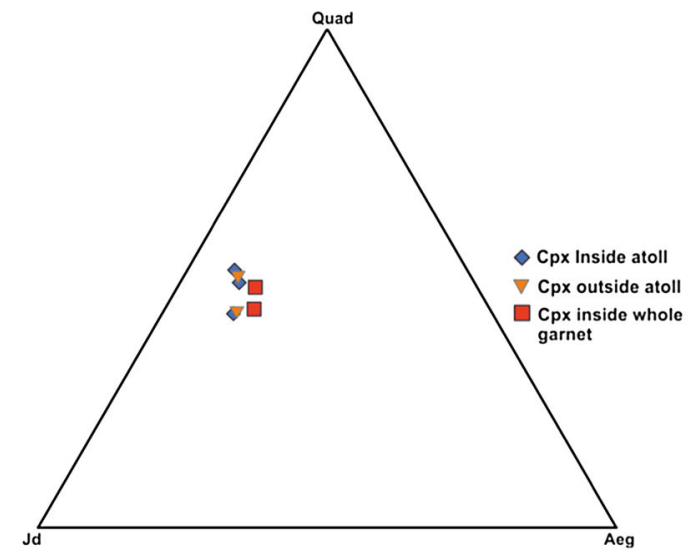

b

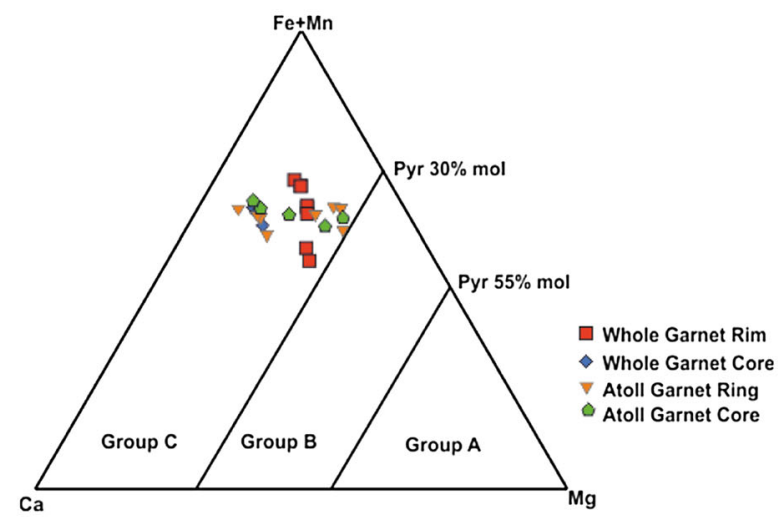

C

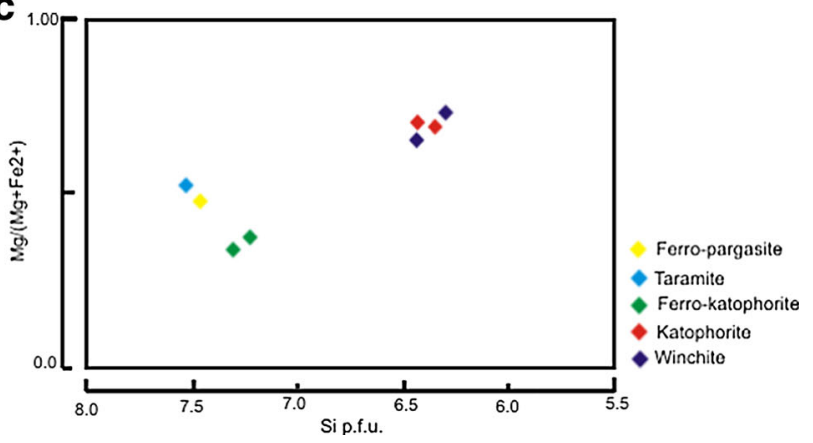

Figure 3. Compositions of minerals in the Tso Morari eclogites. (a) Triangular plots showing chemistry of clinopyroxenes plotted according to Morimoto (1988). (b) Triangular plots showing compositions of garnet. Eclogites belong to Group C based on garnet chemistry (Coleman et al. 1965). (c) Plots showing variation in amphibole chemistry. Amphibole plotted according to Leake et al. (1997).

\subsection{Sample L7}

Garnets exhibiting well-developed atoll structure form a key textural feature in this sample (lat. $33^{\circ} 13^{\prime} 19.9^{\prime \prime} \mathrm{N}$, long. $78^{\circ} 18^{\prime \prime} 42.1^{\prime \prime} \mathrm{E}$ ) and was studied in detail (figure 7). The atoll structure consists of garnet rings enclosing a mixture of several phases with or without island-shaped garnet cores (Passchier and Trouw 1998) (figure 7a).
Atoll structures are more common in the larger grains although these are present in smaller garnet grains. Majority of the garnet grains preserve complete atoll structure with intact cores, but in some garnet grains the cores are disintegrated and thus only atoll structure rings are preserved. The possible stages of atoll structure formation as retrieved from textural study are presented in figure 8. Phengite is the dominant phase within the atoll structures and is occasionally accompanied by omphacite, quartz, feldspar $\left(\mathrm{X}_{\mathrm{Na}}=0.9198 ; \mathrm{X}_{\mathrm{Ca}}=0.2139 ; \mathrm{X}_{\mathrm{K}}=0.5875\right)$ and rarely amphibole (figure $7 \mathrm{~b}$ ). Atolls filled by phengite have sharp and regular internal interfaces that correlate with the crystallographic planes of the garnet. Core and ring compositions of the atoll garnets, like those of whole garnets, show different compositions. Atoll rings are characterized by lower $\mathrm{Ca}, \mathrm{Mn}$ and higher $\mathrm{Mg}$ contents $\left(\mathrm{Grs}_{12-29} \mathrm{Alm}_{54-60} \operatorname{Prp}_{7-29} \mathrm{Sps}_{0.6-1.1}\right)$. Pyrope contents at the atoll rings show a wide variation from inner to outer rings. The atoll cores on the contrary show high $\mathrm{Ca}$ and $\mathrm{Mn}$ and lower $\mathrm{Mg}$ $\left(\mathrm{Grs}_{12-27} \mathrm{Alm}_{59-62} \operatorname{Prp}_{9-17} \mathrm{Sps}_{0.6-0.7}\right)$. Phengite inside the atoll is characterized by $\mathrm{Si}$ content ranging from 3.37 to 3.43 p.f.u. Matrix phengite has Si content of 3.56 p.f.u and is higher than phengite inside the atoll. Larger phengite grains in the matrix exhibit alteration rims that are richer in $\mathrm{Mg}$, but lower in Fe. Amphibole in the atoll garnets are primarily $\mathrm{Na}-\mathrm{Ca}$ rich kataphorite $(\mathrm{Na}(+\mathrm{K})=$ $0.61, \mathrm{Na}(\mathrm{B})=0.95, \mathrm{Na}(\mathrm{A})=0.52$, total $\mathrm{Ca}=$ $0.96, \mathrm{Al}^{\mathrm{iv}}=0.86$ and $\mathrm{Al}^{\mathrm{vi}}=1.13$ ) in composition. Omphacite within the atoll contain $\mathrm{Jd}$ $\left(\mathrm{Jd}_{40-45}, \mathrm{Ae}_{8-12}\right)$ higher than the matrix omphacite $\left(\mathrm{Jd}_{40-44}, \mathrm{Ae}_{10-13}\right)$, but overall show a restricted variation.

Back-scattered electron (BSE) images (figure 9a) and compositional maps illustrate strong zoning in whole garnets with cores being rich in $\mathrm{Ca}\left(\mathrm{X}_{\mathrm{Ca}}=\right.$ $0.29)$ and $\mathrm{Mn}\left(\mathrm{X}_{\mathrm{Mn}}=0.28\right)$, the concentrations of which decrease towards the rims $\left(\mathrm{X}_{\mathrm{Ca}}=0.23\right.$, $\left.\mathrm{X}_{\mathrm{Mn}}=0.19\right)$. In contrast, the cores are depleted in $\mathrm{Mg}$, which increase steadily towards the rims $\left(\mathrm{X}_{\mathrm{Mg}}=0.10-0.24\right)$, characteristic of garnet showing growth zoning. To understand compositional variation better, line profiles for one representative whole garnet grain $\mathrm{A}-\mathrm{A}^{\prime}$ (figure 9b) starting from the rim to the core is presented here. Mn concentrations $<1$ wt $\%(0.60 \mathrm{~mol} \%)$ towards the rim are recorded, whereas in the core $\mathrm{Mn}$ peaks at 1.7 $\mathrm{mol} \% \mathrm{Mg}$ content in the core is $\sim 10 \mathrm{~mol} \%$ and rapidly increase to a maximum of $26 \mathrm{~mol} \%$ at the 

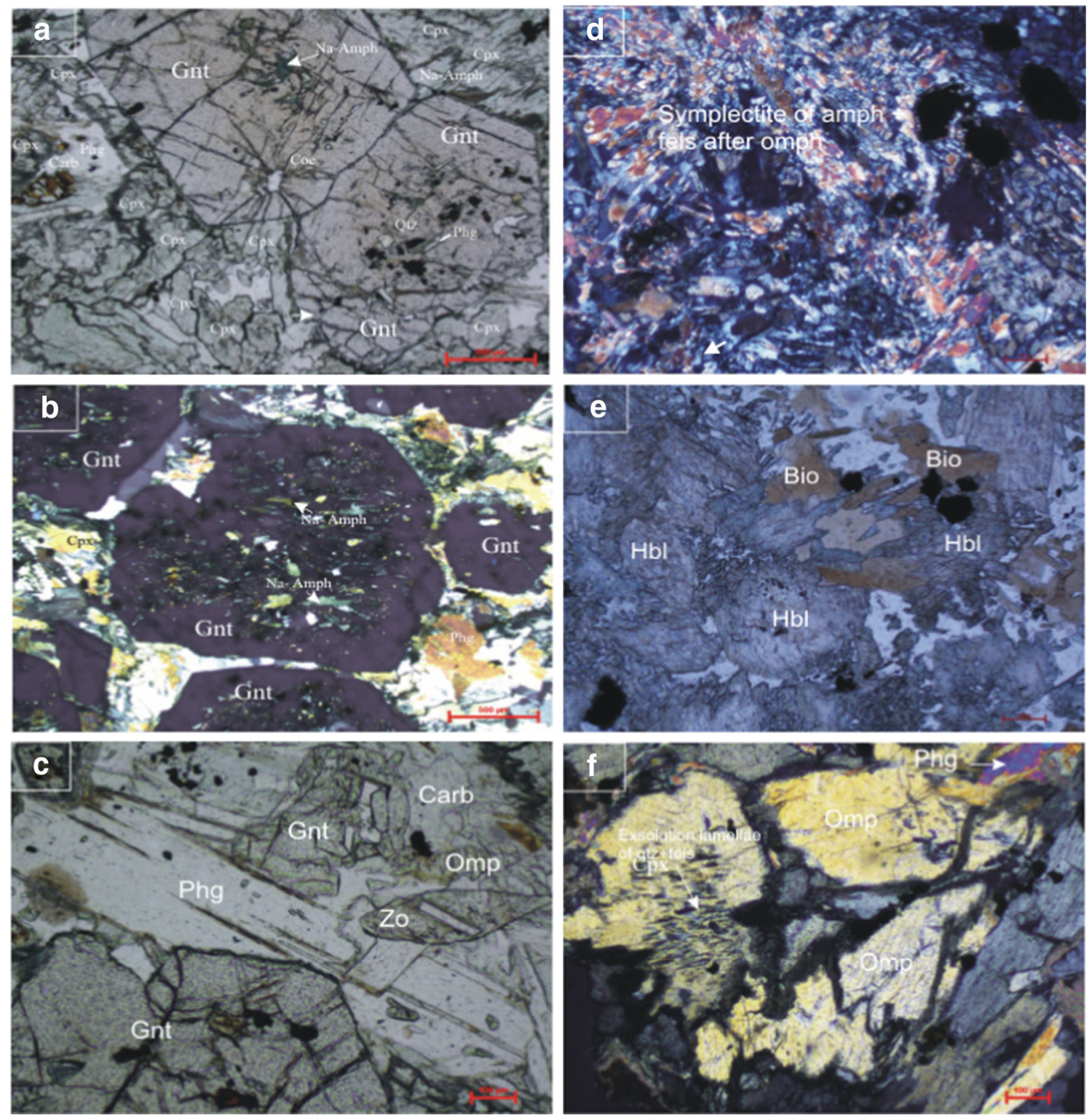

Figure 4. Photomicrographs of the Tso Morari eclogites. (a) Faint pink coloured garnet along with omphacite in the matrix. Note the presence of coesite inclusions towards the garnet rims (PPL). (b) Euhedral garnet with numerous inclusions in the core with dark green rim of Na-amphibole along garnet boundaries. Preferentially aligned Na amphibole inclusions defining the first internal foliation within the garnet cores (BCN). (c) Colourless phengite along with omphacite and epidote (zoisite) and garnet occuring as matrix phases with the Tso Morari eclogites (PPL). (d) Retrogressed eclogites exhibiting varying degrees of amphibolite- and greenschist-facies metamorphism. Symplectitic association of Na-poor clinopyroxene + plagioclase after omphacite (BCN). (e) Breakdown of phengite to biotite and almunious calcic amphiboles (e.g., pargasite) replacing the earlier, high pressure sodic-calcic or sodic amphiboles (PPL). (f) Omphacite cores showing presence of exsolution lamella (BCN). Abbreviations. Gnt: garnet, Cpx: clinopyroxene, Phg: phengite, Coe: coesite, Zo: zoisite, Carb: carbonate, Omp: omphacite, Bio: biotite, Hbl: Hornblende, Na-amp: Na-amphibole, Qtz: quartz.

outer rims with an equally sharp decrease in the Ca content (18 mol\% from $28 \mathrm{~mol} \%$ at the core). $\mathrm{X}_{\mathrm{Mg}}$ (i.e., $\mathrm{Mg} /(\mathrm{Mg}+\mathrm{Fe}))$ is around 0.10 in the cores, rising to 0.26 towards the rims.

BSE images of atoll garnets also show the presence of high $\mathrm{Ca}$ and $\mathrm{Mn}$ cores $\left(\mathrm{X}_{\mathrm{Ca}}=0.28, \mathrm{X}_{\mathrm{Mn}}=\right.$ $0.012)$ with $\mathrm{Mg}$ increasing towards the rims $\left(\mathrm{X}_{\mathrm{Mg}}=\right.$ $0.08-0.27$ ) (figure 9c). Detailed compositional profile across atoll garnet grain 1 (not shown here) clearly indicate lower concentrations of $\mathrm{Ca}$ at the outer rings (13.3 mol\%) with Ca levels increasing steadily inwards (28.9 mol\%). Low Mn (0.89 mol\%) concentrations are observed in the outer rings with Mn increasing towards the inner rings (1.13 mol\%). $\mathrm{Mg}$ peaks in the outer rim at $29.6 \mathrm{~mol} \%$, dropping to $16 \mathrm{~mol} \%$ towards the inner ring. 

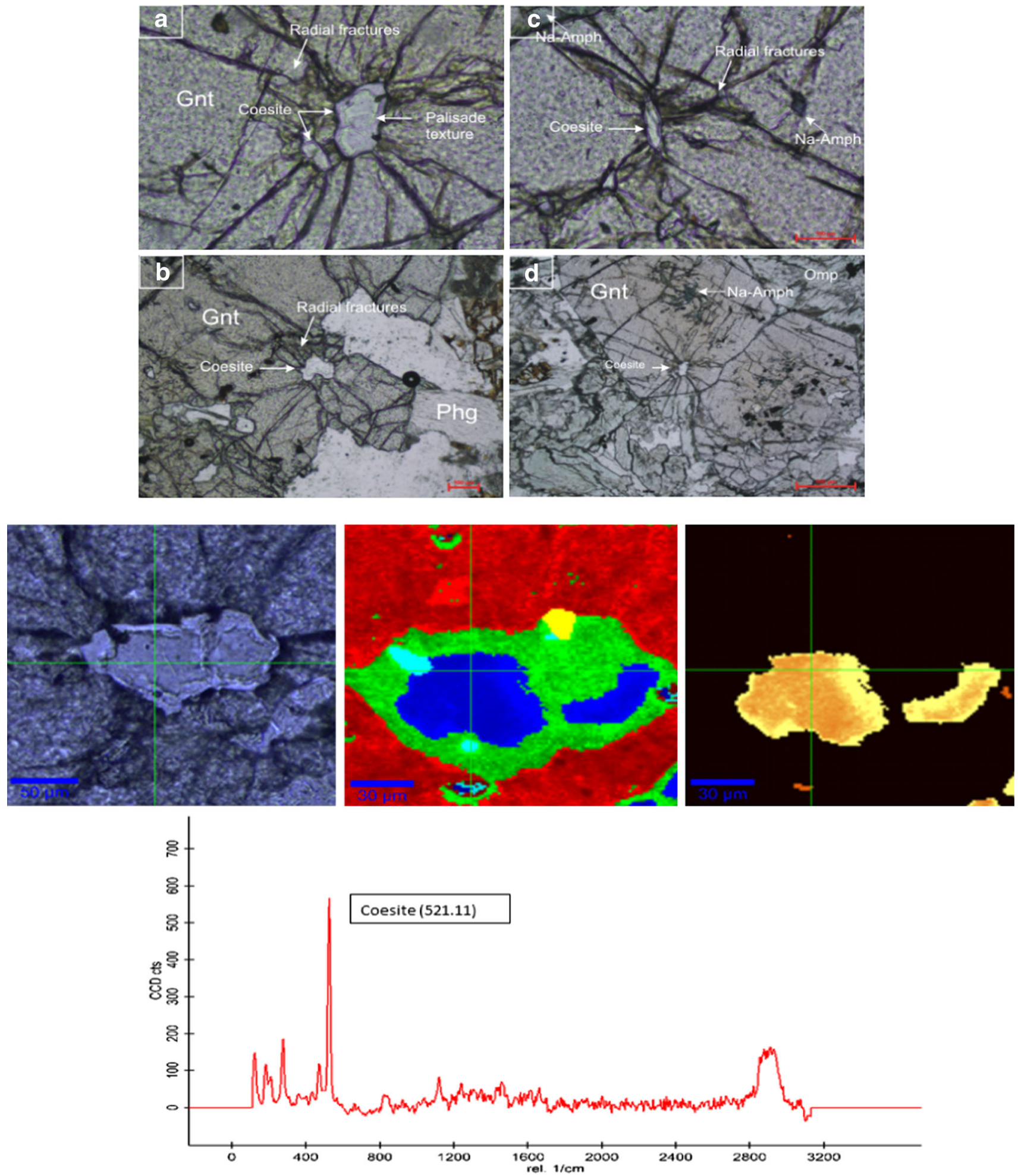

Figure 5. Photomicrographs of quartz pseudomorphs after coesite occurring as inclusions within garnet grains of the Tso Morari Complex. Note the presence of radial fractures extending into the host garnet and thin rim of feathery quartz defining the palisade texture clearly observed in the above photographs (PPL). Colour coded images of the coesite showing the characteristic Raman peak.

In the atoll garnet grain 2, two profiles were studied: one from outer ring to inner ring (D1-D2) and one from garnet Island core (B1-B2) (figure 9d). In D1-D2 profile, Ca concentrations are observed to increase slightly from the outer ring to inner ring (28-32 mol\%). In contrast, the lowest $\mathrm{Mg}$ 


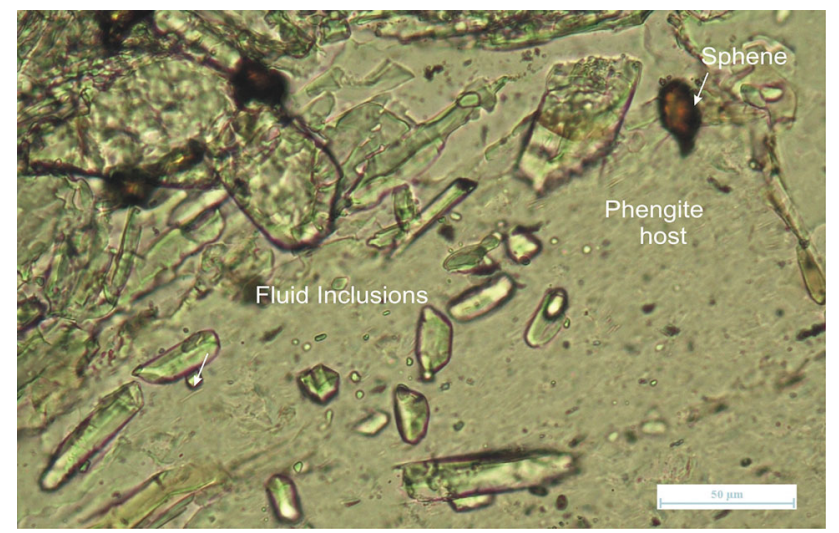

Figure 6. Photomicrographs of fluid inclusions observed in phengite mineral of the eclogites from the Tso Morari complex.
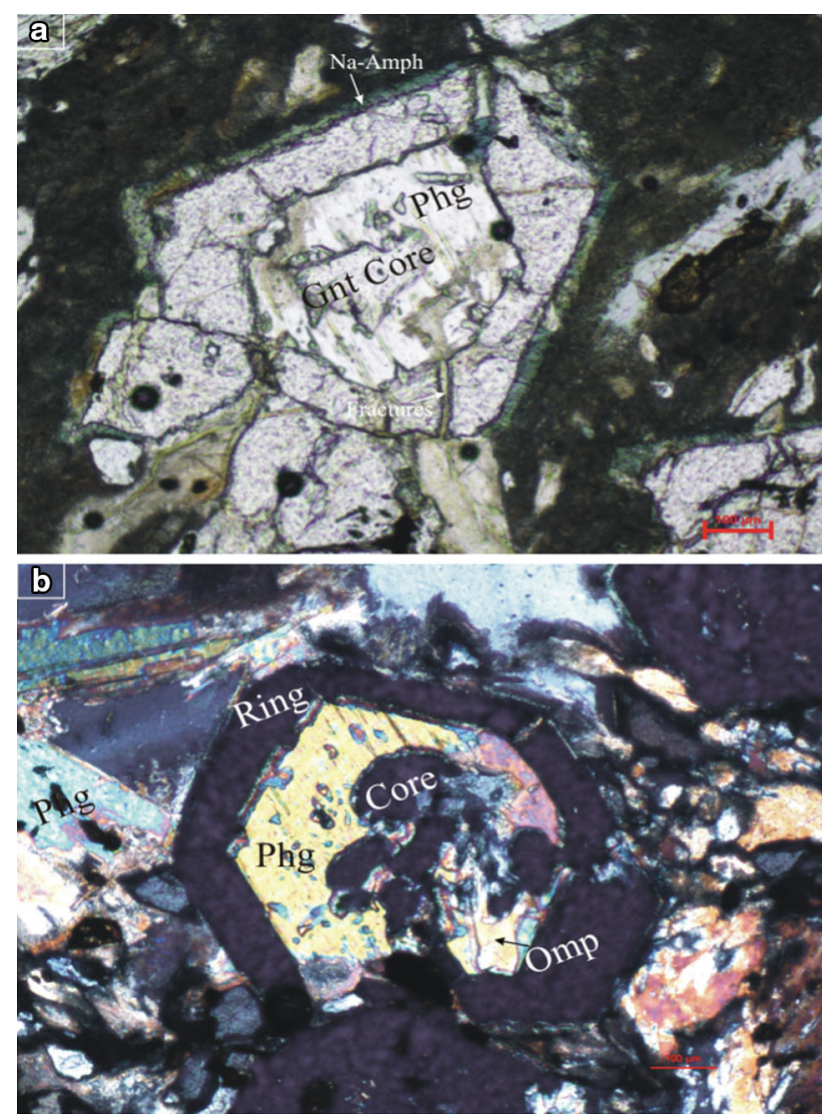

Figure 7. Photomicrographs of atoll garnets of the eclogites from the Tso Morari complex. (a) Euhedral atoll garnet with intact atoll rings preserving an atoll island core in the centre. Phengite is the dominant mineral within the atoll structure. (b) Atoll structure showing the inward growth of atoll peninsulas to form the cores.

(7.7 mol\%) is recorded at the inner ring with higher values observed towards the outer rings (26.9 $\mathrm{mol} \%)$. Mn increases from the outer ring at D1 $(0.64 \mathrm{~mol} \%)$ to inner ring at D2 (1.13 mol\%). Compositional profile across the atoll garnet island core
(B1-B2) shows high Ca concentrations increasing from 16.7 to $27.5 \mathrm{~mol} \%$. Mg drops from $25.7 \mathrm{~mol} \%$ at outer core to $9.32 \mathrm{~mol} \%$ in the inner core.

\section{5. $\mathbf{P}-\mathbf{T}$ estimates}

$\mathrm{P}-\mathrm{T}$ conditions of metamorphism of the Tso Morari eclogites have been constrained from recent studies (e.g., de Sigoyer et al. 2000, 2004; KonradSchmolke et al. 2008; St-Onge et al. 2013; Singh et al. 2013; Chatterjee and Jagoutz 2015; Wilke et al. 2015). The $\mathrm{P}-\mathrm{T}$ path in the present study has been reconstructed from mineral associations stable along the prograde and retrograde paths during the atoll garnet formation of the Tso Morari eclogites and is shown in figure 10 . The $\mathrm{P}-\mathrm{T}$ estimates for the whole and atoll garnets of the Tso Morari eclogites were constrained by using several conventional geothermobarometers (presented in table 2), in particular, the garnet-clinopyroxene (Gnt-Cpx, Krogh 1988; Ravna 2000; uncertainty $\pm 50^{\circ} \mathrm{C}$ ) and garnet-phengite (Gnt-Phg, Green and Hellman 1982; uncertainty $\pm 50^{\circ} \mathrm{C}$ ) $\mathrm{Fe}-\mathrm{Mg}$ exchange thermometers in combination with the garnet-clinopyroxene-phengite (Gnt-Cpx-Phg, Waters and Martin 1993; uncertainties given therein: $\pm 1 \mathrm{kbar}$ and $25^{\circ} \mathrm{C}$ ) geobarometer and the univariant coesite $=$ quartz reaction, $\mathrm{Si}$ content in phengite and the $\mathrm{Alb}=\mathrm{Jd}+\mathrm{Qtz}$ reaction.

As discussed in the previous sections, compositional zoning exists for the garnets and omphacite from the Tso Morari eclogites making temperature estimation for such samples complicated. Another factor affecting temperature estimates is high $\mathrm{Ca}$ and Mn contents in garnet (Krogh 1988; Pattison and Newton 1989). Because the concentration of these elements vary widely from core to rim, and their effect on the temperature estimate is not well understood, the temperature estimates based on Ellis and Green (1979) lead to significant errors. Hence, this method although attempted, has not been considered here.

$\mathrm{P}-\mathrm{T}$ conditions obtained for the whole garnet cores in sample L1 range from $462^{\circ}$ to $508^{\circ} \mathrm{C}$ following the models of Krogh (1988) and Ravna (2000). Temperature of $635^{\circ} \mathrm{C}$ was obtained using the Gnt-Phg thermometer of Green and Hellman (1982). The calculated temperature of $635^{\circ} \mathrm{C}$ seems unreliable as phengite used for calculations is observed as relicts in the matrix and does not occur in the garnet core. Hence, this temperature estimate has not been considered. Pressure 

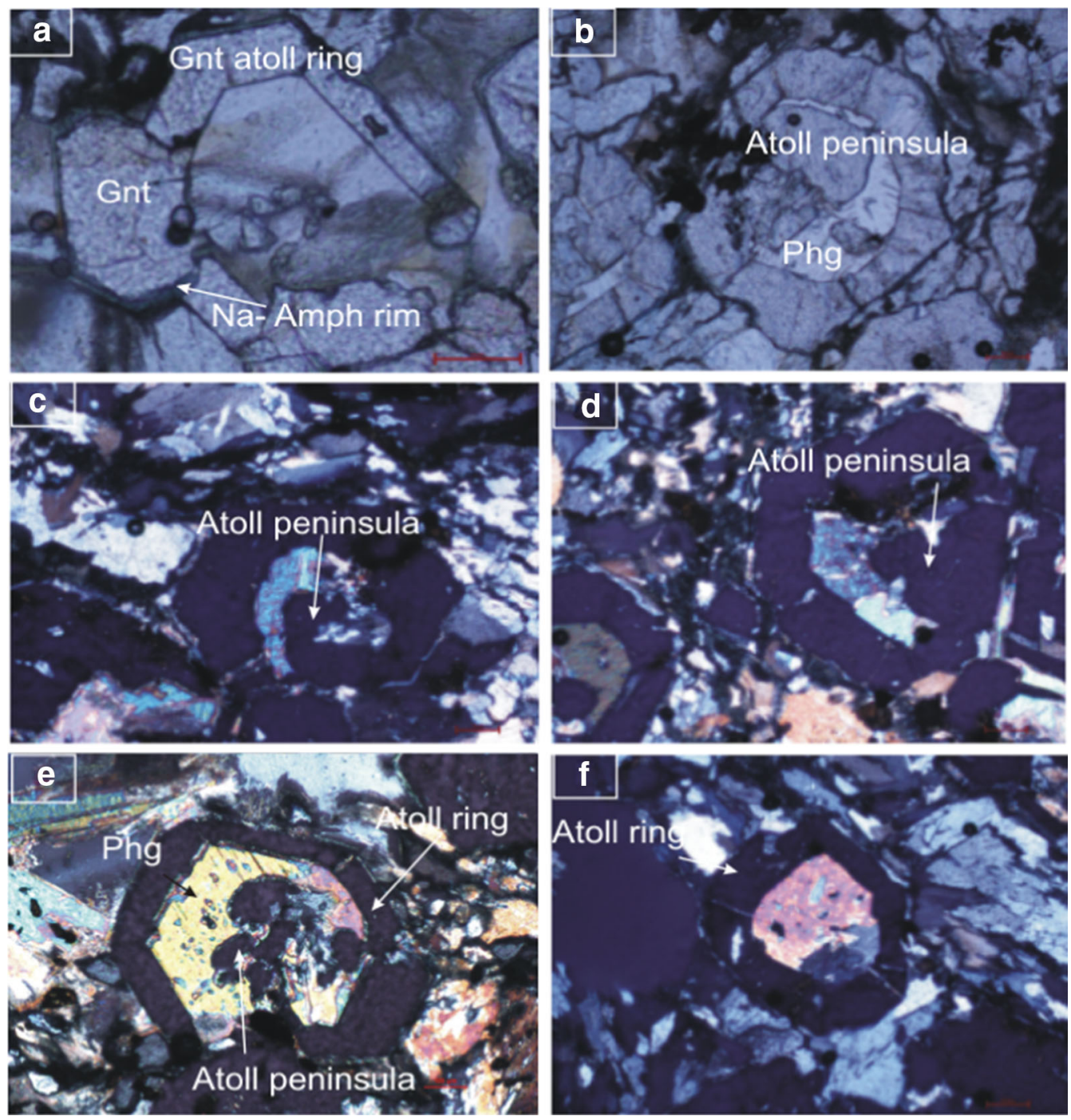

Figure 8. Photomicrographs and textural sketches of the different stages of atoll garnet formation shown by the eclogites. (a) The initial whole garnet, rimmed by Na-amphibole. (b, c and $\mathbf{d}$ ) Phengite mica is present between the atoll rings and central core. The garnet ring extends inwards to form a new core, giving rise to a distinct garnet peninsula; (e) euhedral garnet ring encloses the phengite mica; garnet cores are isolated and detached from the garnet ring and thus form the islands; (f) subhedral garnet grain with an atoll ring enclosing phengite and omphacite; the core may have been completely consumed or not formed at all.

estimation of $2.8 \mathrm{GPa}$ was based on the GntCpx-Phg barometer of Waters and Martin (1993) seems to be an overestimation considering that no convincing Gnt-Cpx-Phg pairs were available for accurate calculation of pressure. Core domains are assumed to yield considerably reliable $\mathrm{P}-\mathrm{T}$ estimates assuming that they have formed in equilibrium and they are shielded from lower temperature $\mathrm{Fe}-\mathrm{Mg}$ exchange during the later stages of metamorphism (Chatterjee and Jagoutz 2015). Therefore, the calculated temperatures of $462^{\circ}-508^{\circ} \mathrm{C}$ are considered as reliable for the whole garnet cores.
Whole garnet with omphacite as inclusions near garnet rim and with coesite inclusions yielded temperature estimates of $561^{\circ}-579^{\circ} \mathrm{C}$ based on models of Krogh (1988) and Ravna (2000). Gnt-Phg thermometer after Green and Hellman (1982) for the whole garnet rims (outer rim with adjacent phengite in matrix) yielded higher temperatures of $768^{\circ} \mathrm{C}$ which could be attributed to high $\mathrm{Mg}$ in the outer rims of garnet and high $\mathrm{Si}$ in phengite (3.56 pfu). Pressure for garnet rims with omphacite inclusions (and coesite) and adjacent phengite were calculated to be $2.65 \mathrm{GPa}$ which is consistent with the minimum pressure of $2.7 \mathrm{GPa}$ based on the 

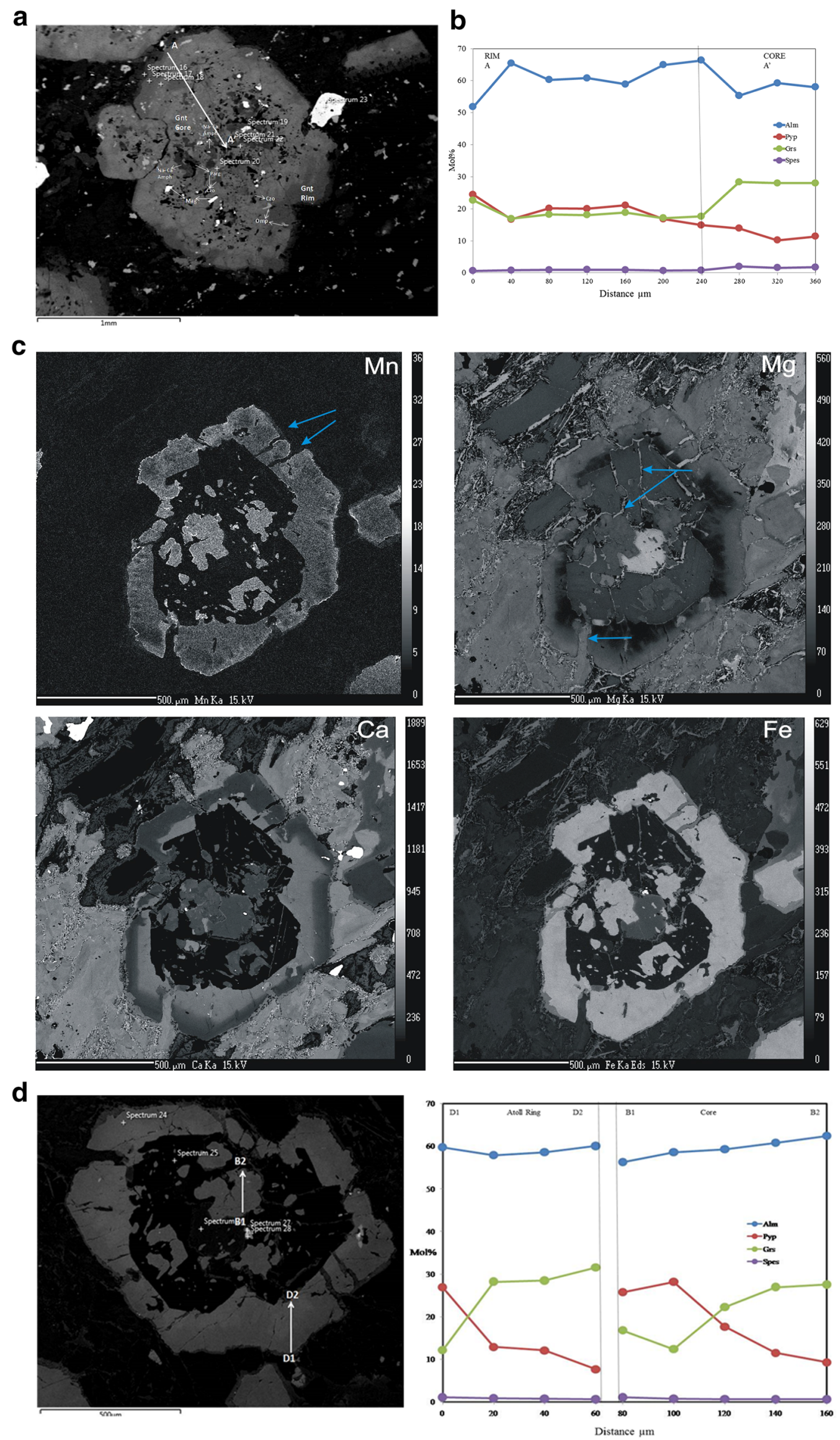
equilibrium of coesite=quartz (Mirwald and Massonne 1980; Bohlen and Boettcher 1982). Considering that omphacite inclusions occur at the inner rim of the whole garnet, the calculated temperature indicates that the inner rim equilibrated at $579^{\circ} \mathrm{C}$ with temperatures increasing to $768^{\circ} \mathrm{C}$ towards the outer rim (with phengite) and shows an increase in temperature across the core-rim interface. $\mathrm{P}-\mathrm{T}$ for the atoll garnets in sample L7 were calculated for inner ring of garnets with coexisting omphacite and phengite inside the atoll structure and with garnet outer ring with neighbouring omphacite and phengite outside the atoll structure.

Garnet-omphacite pairs inside the atoll structure yielded temperature estimates of $483^{\circ}-497^{\circ} \mathrm{C}$ (Traverse 1; Krogh 1988; Ravna 2000), but Traverse 2 yielded much lower temperature of $257^{\circ}-$ $282^{\circ} \mathrm{C}$ at 2.33GPa (Traverse 2; Krogh 1988; Ravna 2000). Garnet-phengite pairs for Traverse 1 yielded high temperature of $675^{\circ} \mathrm{C}$ with traverse 2 yielding a temperature of $614^{\circ} \mathrm{C}$ at $2.33 \mathrm{GPa}$.

Coexisting garnet-omphacite pairs outside the atoll structure gave $\mathrm{P}-\mathrm{T}$ estimates of $365^{\circ}-377^{\circ} \mathrm{C}$ at $2.29 \mathrm{GPa}$ (Krogh 1988; Ravna 2000). GntPhg thermometer yielded higher temperatures of $734^{\circ} \mathrm{C}$. Although $\mathrm{T}-\mathrm{P}$ estimates for the atoll garnet (both inside and outside) have been determined using Gnt-Cpx models of Krogh (1988) and Ravna (2000), the Gnt-Phg model of Green and Hellman (1982) for the atoll garnet is preferred here considering that phengite is the dominant mineral phase inside the atoll structure and $\mathrm{Si}$ compositions in phengite vary proportionately to the $\mathrm{Mg}$ contents of garnet (i.e., highest $\mathrm{Mg}$ garnet and phengite with the highest $\mathrm{Si}$ is observed at outer atoll rings as compared to those from inside the atoll structure).

\section{Discussion}

Chemical zoning in metamorphic garnets is an established tool in evaluating the $\mathrm{P}-\mathrm{T}$ evolution of metamorphic rocks. However, zoning and its

Figure 9. (a) Back scattered images for the whole garnets showing the location of EDS analyses on the grain. (b) Major element zoning profile of the whole garnets across profiles AA' along with representative spectra of the garnet core. (c) $\mathrm{X}$-ray maps for the atoll garnets viz., Mn, Mg, Ca and Fe. Brighter areas represent higher concentrations whereas lower concentrations are darker. Note the presence of cracks and fractures in the atoll garnet indicated by arrows. (d) Back scattered images for the atoll garnet with major element zoning profile across profiles B1-B2 and D1-D2. modification in itself is a complex process. Fluid access, deformation and diffusion along grain- or sub-grain boundaries as well as along fractures are the other variables apart from change in the $\mathrm{P}-\mathrm{T}$ conditions (Joesten 1991; Whitney 1991; Hames and Menard 1993; Florence and Spear 1991).

\subsection{Formation of monocrystalline (whole) garnets}

Mineral chemistry and petrography show that the eclogites do not represent a single equilibrium assemblage. Whole garnets have highest $\mathrm{Ca}$ and $\mathrm{Mn}$ concentrations and lowest $\mathrm{Mg}$ indicating early nucleation and well-defined prograde zonation pattern with an increase in pyrope and decrease in grossular and spessartine contents from core to rim. Inclusions of $\mathrm{Na}-\mathrm{Ca}$ amphibole, zoisite, rutile + magnetite within the garnet cores represent the pre-UHP stage resulting from metamorphism of a mafic protolith and constitute the first preserved prograde association of minerals. Presence of omphacite and coesite inclusions at the garnet outer rims defines the UHP stage evident by highest $\mathrm{Mg}$ towards the garnet rims. With this background, calculated temperatures in the range of $462^{\circ}-508^{\circ} \mathrm{C}$ for garnet cores and temperatures of $768^{\circ} \mathrm{C}$ for garnet rims (with highest $\mathrm{Mg}$ and phengite with the highest $\mathrm{Si}$ content) are consistent with garnet growth during subduction. Previously determined $\mathrm{P}-\mathrm{T}$ conditions of metamorphism for the Tso Morari eclogites are widely variable. This variation could primarily be a result of differing compositions of minerals and their zoning patterns in the samples examined. Using conventional geo-thermobarometry, Mukherjee et al. (2003) reported pressures of $>3.9 \mathrm{GPa}$ at $750^{\circ} \mathrm{C}$, whereas Wilke et al. (2015) calculated temperatures in the range of $560^{\circ}-760^{\circ} \mathrm{C}$ for pressures at about 4.4-4.8 GPa extending subduction depths of $160 \mathrm{~km}$ well within the diamond stability field. Coesite inclusions have been reported from the Tso Morari eclogites (Sachan et al. 2004) and are also confirmed in the present study. However, the presence of microdiamonds remains unconfirmed till date. Hence the pressure estimation of $2.65 \mathrm{GPa}$ calculated for the garnet rims is considered as peak pressure attained during subduction. The above calculated estimate compares well with the $\mathrm{P}-\mathrm{T}$ estimates provided by Palin et al. (2017) of $\sim 2.6-$ $2.8 \mathrm{GPa}$ and $600-620^{\circ} \mathrm{C}$ representing depths of 90-100 km for the Tso Morari eclogites. 

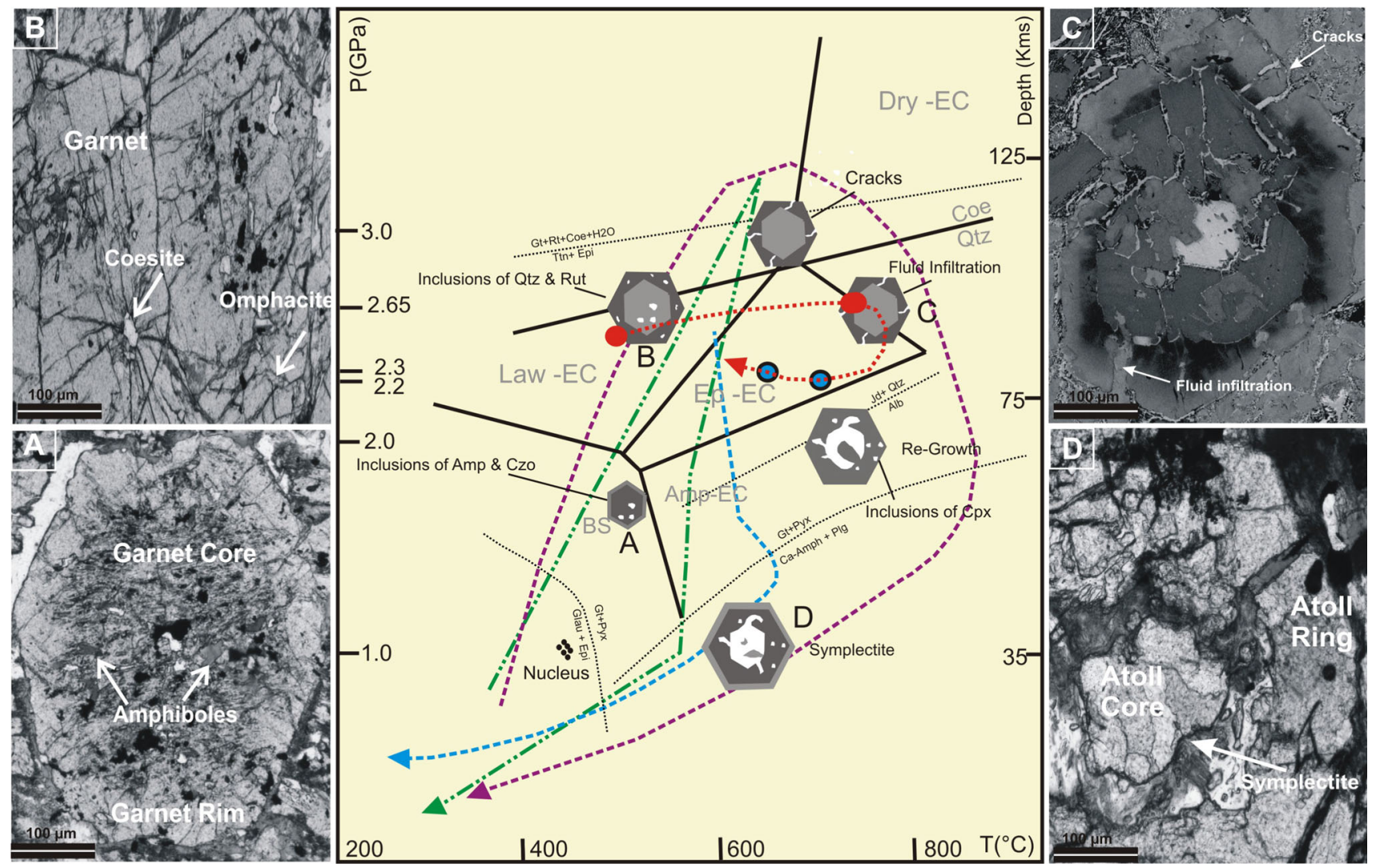

Figure 10. Schematic illusration showing evolution of the whole and atoll garnets along the proposed $\mathrm{P}-\mathrm{T}$ path (red dashed lines). Atoll garnet formation sketches adapted after Cheng et al. (2007) and images A-D represent the textural evidence from the Tso Morari eclogites bearing resemblance to those documented by Cheng et al. (2007). Crucial reactions used for establishing the $\mathrm{P}-\mathrm{T}$ evolution path of the Tso Morari Crystalline Complex have also been marked alongside [Glaucophane (Glau) + Clinozoisite $(\mathrm{Czo}) \leftrightarrow$ Garnet(Gt) + Omphacite(Omph) (Evans 1990), Quatrz(Qtz) $\leftrightarrow$ Coesite(Coe) (Bohlen and Boetcher 1982), Titanite(Ttn) + Epidote(Epi) $\leftrightarrow$ Garnet(Gt) + Rutile(Rt) + Coesite (coe)/Quartz(Qtz) + H ${ }_{2} \mathrm{O}(\mathrm{Man}-$ ning and Bohlen 1991), Jadeite(Jd) + Quartz(Qtz) $\leftrightarrow$ Albite(Ab), (Newton and Smith 1966; Holland 1980), Garnet + Clinopyroxene $\leftrightarrow$ Amphibole + Albite(Plg) (Holland and Powell 1990)]. P-T path proposed by de Sigoyer et al. (2004), Guillot et al. (2008) and Singh et al. (2013) have been shown for comparison by dashed blue, green and purple lines, respectively.

\subsection{Formation of atoll garnets}

Atoll garnets from the studied samples consist of a euhedral ring of garnet that encloses phengite as the dominant mineral phase between the atoll ring and cores. Atoll structures are observed from a single eclogite outcrop in the complex and probably represent a case of accidental preservation of low-strain volumes, as most of the other outcrops are found retrogressed under amphibolite facies. Textural studies indicate that the garnets are more resistant to retrogression and therefore their chemical zonation is still well preserved. This is consistent with theoretical and experimental work (Lasaga et al. 1977; Lasaga 1983) suggesting chemical sluggishness of elements during compositional re-equilibration of garnets.
BSE images and compositional profiles of the atoll garnets suggest chemical zoning different from that of the whole garnet, suggesting their formation at different $\mathrm{P}-\mathrm{T}$ conditions. The peninsula/island cores show high $\mathrm{Ca}$ and $\mathrm{Mn}$ while the outer rings have low $\mathrm{Ca}, \mathrm{Mn}$ and high $\mathrm{Mg}$. This observation argues against the multiple nucleation and coalescence model (Spiess et al. 2001; Dobbs et al. 2003). Temperature estimates based on the GntPhg model of Green and Hellman (1982) show that the atoll garnet rings equilibrated at $734^{\circ} \mathrm{C}$ at slightly lower pressure of $2.29 \mathrm{GPa}$, thus suggesting atoll formation due to decompression upon exhumation.

Presence of primary inclusions in garnet as one of the main reactive sources for atoll garnet formation has been discussed by Smellie (1974). 
Table 2. Thermo-barometric data for the garnets of the Tso Morari complex.

\begin{tabular}{|c|c|c|c|c|c|c|c|}
\hline \multirow{2}{*}{$\begin{array}{l}\text { Metamorphic } \\
\text { Stages }\end{array}$} & \multirow[b]{2}{*}{ Domain } & \multirow[b]{2}{*}{ Minerals used for PT calculations } & \multicolumn{3}{|c|}{ Temperature $\left({ }^{\circ} \mathrm{C}\right)$} & \multicolumn{2}{|c|}{ Pressure (GPa) } \\
\hline & & & RV & $\mathrm{KG}$ & $\mathrm{GH}$ & $\mathrm{BB}$ & WM \\
\hline \multirow[t]{6}{*}{ Whole garnet } & Core & Gnt - Cpx - Phg (in core of Gnt) & & & & & 2.8 \\
\hline & & Gnt - Cpx (in core of Gnt) & 508 & 462 & & & \\
\hline & & Gnt - Phg (in core of Gnt) & & & 635 & & \\
\hline & Rim & Gnt - Cpx - Phg (in rim of Gnt) & & & & & 2.65 \\
\hline & & Gnt - Cpx (in rim of Gnt) & 561 & 579 & & 2.7 & \\
\hline & & Gnt - Phg (Gnt rim and adjPhg) & & & 768 & & \\
\hline \multirow[t]{9}{*}{ Atoll garnet } & $\begin{array}{l}\text { Inside atoll } \\
\quad(\text { Traverse } 1)\end{array}$ & $\begin{array}{c}\text { Gnt - Cpx - Phg (inner rim of atoll } \\
\text { Gnt }+ \text { Phg and Cpx inside atoll) }\end{array}$ & & & & & 2.33 \\
\hline & & $\begin{array}{l}\text { Gnt - Cpx (inner rim atoll Gnt }+ \\
\text { Cpx in atoll Gnt) }\end{array}$ & 483 & 497 & & & \\
\hline & & $\begin{array}{l}\text { Gnt - Phg (Phg inside atoll + inner } \\
\text { rim of Gnt) }\end{array}$ & & & 675 & & \\
\hline & Traverse 2 & $\begin{array}{c}\text { Gnt - Cpx - Phg (Inner rim of atoll } \\
\text { Gnt }+ \text { Phg and Cpx inside atoll) }\end{array}$ & & & & & 2.33 \\
\hline & & $\begin{array}{l}\text { Gnt - Cpx (inner rim atoll Gnt }+ \\
\text { Cpx in atoll Gnt) }\end{array}$ & 257 & 282 & & & \\
\hline & & $\begin{array}{l}\text { Gnt - Phg (Phg inside atoll }+ \text { inner } \\
\text { rim of Gnt) }\end{array}$ & & & 614 & & \\
\hline & Outside atoll & $\begin{array}{c}\text { Gnt - Cpx - Phg (outer rim of atoll } \\
\text { Gnt }+ \text { Phg and Cpx outside atoll) }\end{array}$ & & & & & 2.29 \\
\hline & & $\begin{array}{l}\text { Gnt - Cpx (at outer rim of Gnt } \\
\text { with adjcpx) }\end{array}$ & 377 & 365 & & & \\
\hline & & $\begin{array}{l}\text { Gnt - Phg (outer Gnt rim with } \\
\text { adjPhg) }\end{array}$ & & & 734 & & \\
\hline
\end{tabular}

Formulations used for calculations are RV: Ravna (2000), KG: Krogh (1988), GH: Green and Hellman (1982), WM: Waters and Martin.

Textural and compositional relations in the studied samples show that the atoll garnet rings could be formed by replacement of the inclusionrich whole garnet core simultaneously with the breakdown of matrix phases. Prograde resorption of garnet resulted in removal of $\mathrm{Mn}$ and $\mathrm{Ca}$ from garnet core to contribute to the formation of rims and other phases. Elements released due to the breakdown of initial garnet core were incorporated into the newly-grown $\mathrm{Mg}$-rich garnet rings. In the studied samples, the atolls are filled with phengite (with low $\mathrm{Si}$ ) as the dominant mineral, and the atoll interior show irregular edges that are either embayed or breached. Chemical modification of garnet interiors during metamorphism has been associated with garnet fracturing and is highlighted by many researchers (e.g., Hames and Menard 1993; Whitney 1996; Hwang et al. 2003; Konrad-Schmolke et al. 2007). Compositional resetting of mineral grains along fractures and sub-grain boundaries rapidly occurs when fluids are available and chemical potential gradients are maximized between the matrix and grain interiors
(Konrad-Schmolke et al. 2007). Thompson (1992) postulated that substantial quantities of $\mathrm{H}_{2} \mathrm{O}$ can be transported to depths $>100 \mathrm{~km}$ in the form of hydrous minerals, including phengite, clinohumite and epidote-zoisite. Experimental studies and thermodynamic calculations have demonstrated that lawsonite and phengite are able to store $\mathrm{H}_{2} \mathrm{O}$ below $200 \mathrm{~km}$ in cold subduction zones (Poli and Schmidt 1995). During exhumation, internal retrograde fluids in UHP metamorphic rocks could be derived from the decomposition of hydrous minerals (e.g., Miller et al. 2002; Zheng et al. 2003; Li et al. 2004). Similarly, the decrepitating of primary fluid inclusions (e.g., Xiao et al. 2000, 2001; Su et al. 2002) or the release of structurally bonded $\mathrm{OH}$ from nominally anhydrous minerals (e.g., Zheng et al. 1999, 2003) such as pyroxene, garnet, and rutile can also provide considerable amount of $\mathrm{H}_{2} \mathrm{O}$ in the form of $\mathrm{OH}$ in their crystal lattice (Smyth et al. 1991; Bell and Rossman 1992; Rossman 1996; Ingrin and Skogby 2000; Bolfan-Casanova 2005). As proven by experiments, hydroxyl solubility 
in nominally anhydrous minerals decreases with decreasing pressures ( $\mathrm{Lu}$ and Keppler 1997; Withers et al. 1998; Mosenfelder 2000; Mierdel and Keppler 2004). Thus, significant amounts of aqueous fluids could be released during the early stages of UHP slab exhumation (Zheng et al. 2003). In the Tso Morari eclogites, early assemblages include lawsonite, talc and chlorite which were replaced by zoisite, amphiboles, phengite and quartz during prograde heating (Guillot et al. 1997; Chatterjee and Jagoutz 2015). Evidence of fluid activity in the eclogites from the studied area has already been established by Mukherjee and Sachan (2009). Phase equilibria modelling of post-peak metamorphic mineral assemblages in UHP eclogite from the Tso Morari massif by Palin et al. (2014) show that a number of petrographically distinct hydration episodes have occurred during exhumation $\left(\sim 640^{\circ} \mathrm{C}, 2.7-2.8 \mathrm{GPa}\right)$. Although fluid inclusion studies have not been carried out during the present study, evidence of fluid can be reflected by the continuous presence of hydrous minerals such as zoisite, phengite and amphiboles in the rock matrix of the studied samples. The atoll garnets from the studied samples are therefore understood to have formed by infiltrating fluids generated due to breakdown of hydrous phases and/or the release of structurally bounded $\mathrm{OH}$ from nominally anhydrous minerals such as pyroxene, garnet at the onset of exhumation. The numerous irregular veins and cracks in garnet probably acted as pathways for the transport of fluid resulting in breakdown of garnet cores from inside. Mineral inclusion boundaries inside the original garnets may have also acted as pathways for infiltrating fluids. Re-growth caused by substitution of the garnet from the outer ring towards the inside may perhaps have resulted in the formation of peninsula-shaped atoll structures confirmed by lower temperature of $614^{\circ}-675^{\circ} \mathrm{C}$ estimates for inside the atoll structure. Isolated island-shaped garnet relicts may have been formed by modification of some of the garnet peninsulas during early amphibolite-facies.

\subsection{Tectonic implications}

HP and UHP rocks along the Himalayan belt are observed to occur in different tectonic settings, viz., accretionary wedge, oceanic subduction, continental subduction and continental collision. Rocks of the subducted plate are usually metamorphosed such that these rocks attain peak pressures before peak temperatures defining 'clockwise' $\mathrm{P}-\mathrm{T}$ paths. The metamorphic facies series encountered in subduction tectonic regimes or settings can be characterized by low geothermal gradients: zeolite $\rightarrow$ pumpellyite-actinolitefacies/lawsonite albite facies $\rightarrow$ blueschist facies $\rightarrow$ type $C$ eclogites (Guillot et al. 2008). The reconstruction of the tectonic history of the Tso Morari eclogites proposed below is based on our petrologic study and considers the following constraints: (1) Protoliths for the Tso Morari eclogites are of the Panjal Traps (de Sigoyer et al. 2004) and areas old as Late Permian (Spencer et al. 1995), whereas the metamorphic ages are as young as Early Eocene (Leech et al. 2005); (2) the eclogites have been deformed at least two times; one was synchronous with prograde metamorphism during subduction and the other was related to amphibolite facies retrograde metamorphism during exhumation; (3) The eclogites have been subjected to at least three stages of metamorphism where the subducted rocks attain peak pressures prior to peak temperatures represented by a clockwise $\mathrm{P}-\mathrm{T}$ time path.

The protoliths for the Tso Morari eclogites believed to have originated from mafic dykes (Ahmad et al. 2006) traversing through the northern Indian plate, thus representing the leading margin of the Indian plate which subducted beneath the Tethyan oceanic lithosphere. Subduction of the leading edge of the Indian plate with Late Permian continental eclogite protoliths represent an A-type subduction model of the Indian and Asian Plates at $56 \pm 3 \mathrm{Ma}$ (Guillot et al. 2008 and the references therein). The continental crustal fragment was probably dragged into subduction beneath the Asian plate after the intervening oceanic crust was completely consumed. During subduction, the crust went through various $\mathrm{P}-\mathrm{T}$ conditions resulting in phase changes from blueschist (represented by inclusions in whole garnet) due to rapid increase in pressure and temperature to the eclogite facies assemblage represented by presence of coesite in the studied samples at depths of more than 100 $\mathrm{km}\left(768^{\circ} \mathrm{C} / 2.65 \mathrm{GPa}\right)$. At this depth, the Indian plate became gravitationally unstable because of its low density causing it to rebound isostatically initiating the exhumation process and thus causing uplift of the continental fragment allowing pressure to be released faster than temperature. Preservation of type $\mathrm{C}$ eclogites as well as blueschist facies assemblages is important considering that they are characterized by clockwise $\mathrm{P}-\mathrm{T}$ paths, and may undergo heating and decompression during their 
exhumation. High temperatures of $400^{\circ}-425^{\circ} \mathrm{C}$ at 2.2-2.3 GPa to $670^{\circ}-720^{\circ} \mathrm{C}$ at $1.8-1.9 \mathrm{GPa}$ during the early stages of exhumation have been reported by Chatterjee and Jagoutz (2015) and are consistent with the estimated temperatures of $497^{\circ} \mathrm{C}$ at $2.3 \mathrm{GPa}$ for outer garnet rings supporting their formation during exhumation. Relict coesite inclusions with well-developed radiating fractures in the garnet rims of the studied samples resulted due to the volume increase during the transformation from coesite to palisade quartz further support decompression during exhumation. Retrograde assemblage after omphacite consists of a symplectic intergrowth of clinopyroxene and albite; such replacement is very common and preserved in the studied eclogites where omphacite is more severely retrograded than garnet. During exhumation up to the depth of $40-30 \mathrm{~km}$, the Tso Morari rocks underwent cooling under blueschist facies conditions (1.1 $\pm 0.3 \mathrm{GPa} ; 580 \pm 50^{\circ} \mathrm{C}$; Guillot et al. 2008). The amphibolite facies $(1.1 \pm 0.2 \mathrm{GPa}$ and $630 \pm 50^{\circ} \mathrm{C}$; ibid.) metamorphism is established at $47 \pm 0.5 \mathrm{Ma}$ by using variety of methods (de Sigoyer et al. 2000; Leech et al. 2005). Further, retrogression is characterized by the development of chlorite and chloritoid, which surrounds the garnet and along with white mica occur as shear bands (0.5 $\mathrm{GPa}$ and $500^{\circ} \mathrm{C}$ ibid) in the entire Tso Morari massif, and mark the final deformation which is dated between $34 \pm 2$ and $45 \pm 2$ Ma by Schlup et al. (2003).

\section{Conclusions}

The UHP eclogites from the Tso Morari complex contain whole garnets along with spectacular atoll garnet structures. The atoll structures consist of garnet rings enclosing mixture of mineral phases between the rings and island cores.

(1) The atoll garnets are formed due to breakdown of the cores of earlier whole garnets as a result of infiltrating fluids at the onset of exhumation.

(2) The elements released due to this breakdown were incorporated in the later-forming atoll rings from the outer rings towards the inside, resulting in peninsula-shaped atoll garnet cores.

(3) Compositional heterogeneity between the whole garnet cores and rims, and atoll rings indicate their formation under differing $\mathrm{P}-\mathrm{T}$ conditions.

(4) Previously determined $\mathrm{P}-\mathrm{T}$ paths for the Tso Morari eclogites show that the garnet cores and rims more or less equilibrated at 2.0-2.15 GPa at temperatures of $535^{\circ}-580^{\circ} \mathrm{C}$ (de Sigoyer et al. 1997; St-Onge et al. 2013) suggesting isothermal decompression.

(5) However, new temperature estimates calculated during the present study show that the whole garnet cores were formed at lower temperatures as compared to the rims suggesting formation under a prograde sequence from blueschist to eclogite facies.

(6) The atoll garnets are characterized by overall lower temperatures than the whole garnets and support their formation during the early stages of exhumation.

Paragenesis and composition of minerals from eclogites suggest that these rocks have experienced at least three stages of metamorphism, i.e., an earlier stage of blueschist facies metamorphism before they were subjected to an ultrahigh-pressure metamorphism of the coesite-eclogite facies followed by the epidote-amphibolite facies and greenschist facies retrograde stages during uplift. The subducted rocks attain peak pressures prior to peak temperatures represented by a clockwise $\mathrm{P}-\mathrm{T}$ path.

\section{Acknowledgements}

The authors thank the Head, Department of Geology, Savitribai Phule Pune University, for providing the necessary facilities. Thanks are also due to Prof. S Y O'Reilly, for providing access to analytical facilities and for constant encouragement. This is contribution from the ARC Centre of Excellence for Core to Crust Fluid Systems (http:// www.ccfs.mq.edu.au) and in the GEMOC Key Centre (http://www.gemoc.mq.edu.au). The analytical data were obtained using instrumentation funded by DEST Systemic Infrastructure Grants, ARC LIEF, NCRIS/AuScope, industry partners and Macquarie University. MKJ acknowledges the financial support received from CSIR, New Delhi by means of SRF (9/137/(0499)/2011-EMR-I). The authors thank BCUD, Savitribai Phule Pune University for financial support received through BCUD research project grants.

\section{References}

Ahmad T, Tanaka T, Sachan H K and Mukherjee B 2006 Petrogenesis of coesite bearing Tso Morari eclogites; Isotopic 
and elemental constrains in 21 Himalayan KarakoramTibet workshop, S.I.; Abstract volume, J. Asian Earth Sci. 26121.

Bell D R and Rossman G R 1992 Water in Earth's mantle - the role of nominally anhydrous minerals; Science $\mathbf{2 5 5}$ 1391-1397.

Berthelsen A 1953 On the geology of the Rupshu district, northwest Himalaya; Medd. Dansk Geol. Foren. 12 350414.

Bohlen S R and Boettcher A L 1982 The quartz-coesite transformation: A precise determination and effects of other components; J. Geophys. Res. 87 7073-7078.

Bolfan-Casanova N 2005 Water in the Earth's mantle; Mineral. Mag.69 229-257.

Carswell D A 1990 Eclogites and the eclogite facies rocks: Definitions and classification; In: Eclogite facies rocks (ed.) Carswell D A; Blackie Glasgow and London 113.

Chatterjee N and Jagoutz O 2015 Exhumation of the UHP Tso Morari eclogite as a diapir rising through the mantle wedge; Contrib. Mineral. Petrol. 1693.

Chen D, Liu L and Liu X 2011 Atoll garnet in the Yukahe UHP eclogite: Evidence for melt/fluid activity during the eclogitic facies metamorphism; Mineral. Mag. 75650.

Cheng H, Nakamura E, Kobayashi K and Zhou Z 2007 Origin of atoll garnets in eclogites and implications for the redistribution of trace elements during slab exhumation in a continental subduction zone; Am. Mineral. 921119 1129.

Chopin C 1984 Coesite and pure pyrope in high-gradeblueschists of the Western Alps: A first record and some consequences; Contrib. Mineral. Petrol. 86 107-118.

Colchen M, Mascle G and Delaygue G 1994 Lithostratigraphy and age of the formations in the Tso Morari dome; $J$. Nepal Geol. Soc. 1023.

Coleman R G, Lee D E, Beatty L B and Brannock W W 1965 Eclogites and eclogites: Their differences and similarities; Geol. Soc. Am. Bull. 76 483-508.

Deer W A, Howie R A and Zussman J 1992 An introduction to the rock forming minerals; ELBS Publ., UK, 696p.

de Sigoyer J, Chavagnac V, Toft J B, Villa I M, Luais B, Guillot S, Cosca M and Mascle G 2000 Dating the Indian continental subduction and collisional thickening on the NW Himalayas-Multichronology of the Tso Morari eclogites; Geology 28 487-490.

de Sigoyer J, Guillot S and Dick P 2004 Exhumation of the ultra high pressure Tso Morari unit in eastern Ladakh NW Himalayas: A case study; Tectonics 23 1-18.

de Sigoyer J, Guillot S, Lardeaux J M and Mascle G 1997 Glaucophane bearing eclogites in the Tso Morari dome eastern Ladakh NW Himalaya; Eur. J. Mineral. 9 10731083.

Ding L, Zhong D L, Yin A, Kapp P and Harrisson T M 2001 Cenezoic structural and metamorphic evolution of the eastern Himalayan syntaxis (Namche Barwa); Earth Planet Sci. Lett. 192 423-438.

Di Pietro J A and Pogue K R 2004 Tectonostratigraphic subdivisions of the Himalaya: A view from the west; Tectonics. 23, https://doi.org/10.1029/2003TC001554.

Dobbs H T, Peruzzo L, Seno F, Spiess R and Prior D J 2003 Unraveling the Schneeberg garnet puzzle. A numerical model of multiple nucleation and coalescence; Contrib. Mineral. Petrol. 146 1-9.
Donaldson D, Webb A A G, Menold C A, Kylander-Clark A R C and Hacker B R 2013 Petrochronology of Himalayan ultrahigh-pressure eclogite; Geology 41 835-838.

Ellis D J and Green D H 1979 An experimental study of the effect of $\mathrm{Ca}$ upon garnet-clinopyroxene $\mathrm{Fe}-\mathrm{Mg}$ exchange equilibria; Contrib. Mineral. Petrol. 71 12-22.

Epard J L and Steck A 2008 Structural development of the Tso Morari ultra-high pressure nappe of the Ladakh Himalaya; Tectonophys. 451 242-264.

Evans B W 1990 Phase relations of epidote blueschists; Lithos 25 3-23.

Faryad S W, Klápová H and Nosál L 2010 Mechanism of formation of atoll garnet during high-pressure metamorphism; Mineral. Mag. 74 111-126.

Faryad S W and Hoinkes G 2004 Complex growth textures in a polymetamorphic metabasite from the Kraubath Massif Eastern Alps; J. Petrol. 45 1441-1451.

Florence F P and Spear F S 1991 Effects of diffusional modification of garnet growth zoning on $\mathrm{P}-\mathrm{T}$ path calculations; Contrib. Mineral. Petrol. 107 487-500.

Forestier F H and Lasnier B 1969 Découverte de niveaux d'amphibolites à pargasite anorthite corindon et saphirine dans les schistes cristallins de la vallée du Haut-Allier - Existence du faciès granulite dans la massif central Français; Contrib. Mineral. Petrol. 23 194-235.

Fumagalli P and Poli S 2005 Experimentally determined phase relations in hydrous peridotites to $65 \mathrm{GPa}$ and their consequences on the dynamics of subduction zones; $J$. Petrol. 463 555-578.

Ghent E D 1989 A review of chemical zoning in eclogite garnets; In: Eclogites and Eclogite-Facies Rocks (ed.) Smith D C, Elsevier Sci. Publ., pp. 207-235.

Gillet P Ingrin J and Chopin C 1984 Coesite in subducted continental crust: $\mathrm{P}-\mathrm{T}$ history deduced from an elastic model; EPSL 70 426-436.

Green J F N 1915 The garnets and streaky rocks of the English Lake District; Mineral. Mag. 17 207-217.

Green T H and Hellman P L 1982 Fe-Mg partition between coexisting garnet and phengite at high pressure and comments on a garnet phengite geothermometer; Lithos $\mathbf{1 5}$ $253-266$.

Griffin W L and Brueckner H K 1980 Caledonian Sm-Nd ages and a crustal origin for Norwegian eclogites; Nature 285 319-321.

Griffin W L and Carswell D A 1985 In situ metamorphism of Norwegian eclogites: An example; In: The Caledonide Orogen (eds) Gee D G and Sturt B A, Wiley New York, pp. $813-822$.

Griffin W L and Qvakem H 1985 Superferrian eclogites and the crustal origin of garnet peridotites Almklovdalen Norway; In: The Caledonide Orogen (eds) Gee D G and Sturt B A, Wiley New York, pp. 804-812.

Guillot S, de Sigoyer J, Lardeaux J M and Mascle G 1997 Eclogitic metasediments from the Tso Morari area Ladakh Himalaya: Evidence for continental subduction during India-Asia convergence; Contrib. Mineral. Petrol. 128 197-212.

Guillot S, Hattori K, de Sigoyer J, Nägler T and Auzende A L 2001 Evidence of hydration of the mantle wedge and its role in the exhumation of eclogites; EPSL 193 115-127.

Guillot S, Garzanti E, Baratoux D, Marquer D, Maheo G and de Sigoyer J 2003 Reconstructing the total shortening 
history of the NW Himalaya; Geochem. Geophys. Geosyst. 4, https://doi.org/10.1029/2002GC000484.

Guillot S, Mahéo G, de Sigoyer J, Hattori K H and Pêcher A 2008 Tethyan and Indian subduction viewed from the Himalayan high- to ultrahigh-pressure metamorphic rocks; Tectonophys. 451 225-241.

Hames W E and Menard T 1993 Fluid-assisted modification of Garnet composition along rims cracks and mineral inclusion boundaries in samples of amphibolite facies schists; Am. Mineral. 78 338-344.

Hickmott D D, Shimizu N, Spear F S and Selverstone J 1987 Trace-element zoning in a metamorphic garnet; Geology 15 573-576.

Hirsch D M, Prior D J and Carlson W D 2003 An overgrowth model to explain multiple dispersed high-Mn regions in the cores of garnet porphyroblasts; Am. Mineral. 88 131141.

Holland J B 1980 The reaction albite $=$ jadeite + quartz determined experimentally in the range $600^{\circ} \mathrm{C}-1200^{\circ} \mathrm{C}$; Am. Mineral. 65 129-134.

Holland J B 1983 The experimental determination of activities in disordered and short-range ordered jadeitic pyroxenes; Contrib. Mineral. Petrol. 82 214-220.

Holland T J B and Powell R 1990 An enlarged and updated internally consistent thermodynamic data set with uncertainties and correlations: The system K2O-Na2O-CaOMgO-FeO-MnO-Fe2O3-TiO2-SiO2C-H2-O2; J. Metamorph. Geol. 8 89-124.

Hollister L S 1966 Garnet zoning: An interpretation based on the Rayleigh fractionation model; Science 154 1647-1651.

Hwang S L, Shen P, Yui T F and Chu H T 2003 On the mechanism of resorption zoning in metamorphic garnet; J. Meta. Geol. 21 761-769.

Ingrin J and Skogby H 2000 Hydrogen in nominally anhydrous upper-mantle minerals: Concentration levels and implications; Eur. J. Mineral. 12 543-570.

Jain A K, Singh S, Manickavasagam R M, Josh M and Verma P K 2003 HIMPROBE programme: Integrated studies on geology petrology geochronology and geophysics of the trans-Himalaya and Karakoram; Geol. Soc. India Memoir $\mathbf{5 3}$ 56p.

Joesten R 1991 Grain boundary diffusion kinetics in silicate and oxide minerals; In: Diffusion, Atomic Ordering and Mass Transport; Springer Berlin, pp. 345-395.

Kaneko Y, Katayama I, Yamamoto H, Misawa K, Ishikawa M, Rehman H U, Kausar A B and Shiraishi K 2003 Timing of Himalayan ultra high pressure metamorphism: Sinking rate and subduction angle of the Indian continental crust beneath Asia; J. Meta. Geol. 21 589-599.

Kayleigh H M, Dennis D, Carrie M A, Webb A and Alexander G 2014 Pressure-temperature-time constraints for UHP Tso Morari eclogite NW India; GSA Annual Meeting in Vancouver, British Columbia.

Kohn M J 2003 Geochemical zoning in metamorphic minerals in the crust; Treatise on Geochemistry, Amsterdam Elsevier 3 229-261.

Kohn M and Spear F S 2000 Retrograde net transfer reaction insurance for pressure-temperature estimates; Geology $\mathbf{2 8}$ 1127-1130.

Konrad-Schmolke M, O'Brien P J and Heidelbach F 2007 Compositional re-equilibration of garnet: The importance of sub-grain boundaries; Eur. J. Mineral. 19 431-438.
Konrad-Schmolke M, O'Brien P-J, de Capitani C and Carswell D A 2008 Garnet growth at high- and ultra-high pressure conditions and the effect of element fractionation on mineral modes and composition; Lithos 103309 332.

Krogh E 1988 The garnet-clinopyroxene iron-magnesium geothermometer - a reinterpretation of existing experimental data, Contrib. Mineral. Petrol. 99 44-48.

Lanari P, Riel N, Guillot S, Vidal O, Schwartz O, Pêcher A and Hattori K H 2013 Deciphering high-pressure metamorphism in collisional context using microprobemapping methods: Application to the Stakeclogitic massif NW-Himalaya; Geology 41 111-114.

Lappin M A and Smith D C 1978 Mantle-equilibrated orthopyroxene eclogite pods from the basal gneisses in the Selje district western Norway; J. Petrol. 19 530-584.

Lasaga A C, Richardson S M and Holland H D 1977 The mathematics of cation diffusion and exchange between silicate minerals during retrograde metamorphism; In: Energetics of geological processes (eds) Saxena S K and Bhatacharji S, Springer Verlag, New York, pp. 353-388.

Lasaga A C 1983 Geo-speedometry: An extension of geothermometry; In: Kinetics and Equilibrium in Mineral Reactions (ed.) Saxena S K, Springer Verlag, New York, 3 81-114.

Leake B E, Woolley A R, Arps C E S, Birch W D, Gilbert M C, Grice J D, Howthorne F C, Kato A, Kisch H J, Krivovichev V G, Linthout K, Laird J and Mandarino J A 1997 Nomenclature of amphiboles report of the subcommittee on amphiboles of the International Mineralogical Association: Commission on new mineral names; Mineral. Mag. 61 295-321.

Leech M L, Singh S, Jain A K and Manickavasagam R M 2003 New U-Pb shrimp ages for the UHP Tso Morari Crystallines Ladakh India; The Geological Society of America (GSA) Annual Meeting, Seattle, USA, abs No: 61682 260-264.

Leech M L, Singh S, Jain A K, Klemperer S L and Manickavasagam R M 2005 The onset of India-Asia continental collision: Early steep subduction required by the timing of UHP metamorphism in W Himalaya; EPSL 23483 97.

Li X P, Zheng Y F, Wu Y B, Chen F K, Gong B and Li Y L 2004 Low-T eclogite in the Dabie terrane of China: Petrological and isotopic constraints on fluid activity and radiometric dating; Contrib. Mineral. Petrol. 148 443-470.

Loomis T P 1975 Reaction zoning of garnet; Contrib. Mineral. Petrol. 52 285-305.

Lu R and Keppler H 1997 Water solubility in pyrope to 100 kbar; Contrib. Mineral. Petrol. 129 35-42.

Mahéo G, Bertrand H, Guillot S, Villa I M, Kellerc F and Capiez P 2004 The south Ladakh ophiolites (NW Himalaya India): An intra-oceanic tholeiitic arc origin with implication for the closure of the Neo-Tethys; Chem. Geol. 203 273-303.

Menard T and Spear F S 1993 Metamorphism of calcic pelitic schists Strafford Dome Vermont: Compositional zoning and reaction history; J. Petrol. 34 977-1005.

Mierdel K and Keppler H 2004 The temperature dependence of water solubility in enstatite; Contrib. Mineral. Petrol. $148305-311$. 
Miller J A, Buick I S, Cartwright I and Barnicoat A 2002 Fluid processes during the exhumation of high-P metamorphic belts; Mineral. Mag. 66 93-119.

Mirwald P W and Massonne H J 1980 Quartz coesite transition and the comparative friction measurements in piston-cylinder apparatus using talc-alsimag-glass (TAG) and $\mathrm{NaCl}$ high pressure cell: A discussion; J. Mineral. Geochem. 10 469-477.

Morimoto N 1988 Nomenclature of Pyroxenes; Am. Mineral. 73 1123-1133.

Mosenfelder J L 2000 Pressure dependence of hydroxyl solubility in coesite; Phys. Chem. Min. 27 610-617.

Mottana A, Carswell D A, Chopin C and Oberhansi R 1990 Eclogite facies mineral parageneses; In: Eclogite facies mineral parageneses (ed.) Carswell D A, Blackie (Glasgow and London), pp. 14-52.

Mukherjee B K and Sachan H K 2001 Discovery of coesite from Indian Himalaya: A record of ultrahigh pressure metamorphism in Indian continental crust; Curr. Sci. 81 1358-1361.

Mukherjee B K and Sachan H K 2009 Fluids in coesitebearing rocks of the Tso Morari Complex NW Himalaya: Evidence for entrapment during peak metamorphism and subsequent uplift; Geol. Mag. 146 876-889.

Mukherjee B K, Sachan H K, Ogasawaray Y, Muko A and Yoshioka N 2003 Carbonate-bearing UHPM rocks from the Tso-Morari Region Ladakh India: Petrological implications; Int. Geol. Rev. 45 49-69.

Mukherjee S and Mulchrone K F 2012 Estimating the viscosity and Prandtl number of the Tso Morari crystalline gneiss dome Indian western Himalayas; Int. J. Earth Sci. 101 1929-1947.

Newton R C and Smith J V 1966 Investigations concerning the breakdown of albite at depth in the earth; J. Geol. 75 $268-286$.

O'Brien P J and Sachan H K 2000 Diffusion modeling in garnet from the Tso-Morari eclogite and implications for exhumation models; 15th HKT workshop Chengdu China Earth Sci. Frontiers, China Univ. Sci. 7 25-27.

O'Brien P J, Zotov N, Law R, Khan M A and Jan M Q 2001 Coesite in Himalyan eclogite and implications for models of India-Asia collision; Geology 29 435-438.

Palin R M, St-Onge M R, Waters D J, Searle M P and Dyck B 2014 Phase equilibria modelling of retrograde amphibole and clinozoisite in mafic eclogite from the Tso Morari massif, northwest India: Constraining the P-T-M $\left(\mathrm{H}_{2} \mathrm{O}\right)$ conditions of exhumation; J. Meta. Geol. 32 675-693.

Palin R M, Reuber G S, White R W, Kaus B J P and Weller O M 2017 Subduction metamorphism in the Himalayan ultrahigh-pressure Tso Morari massif: An integrated geodynamic and petrological modelling approach; EPSL 467 108-119, https://doi.org/10.1016/j.epsl.2017.03.029.

Parrish R R, Gough S J, Searle M P and Waters D J 2006 Plate velocity exhumation of UHP eclogites in the Pakistan Himalayas; Geology 34 989-992.

Passchier C W and Trouw R A J 1998 Microtectonics; Springer Berlin, 289p.

Pattison D R M and Newton R C 1989 Reversed experimental calibration of the garnet-clinopyroxene $\mathrm{Fe}-\mathrm{Mg}$ exchange thermometer; Contrib. Mineral. Petrol. 10187 103.
Peacock S M 1993 The importance of blueschist-eclogite dehydration reactions in subducting oceanic crust; Geol. Soc. Am. Bull. 105 684-694.

Perchuk A, Philippot P, Erdmer P and Fialin M 1999 Rates of thermal equilibration at the onset of subduction deduced from diffusion modeling of eclogitic garnets Yukon-Tanana terrane Canada; Geology 27 531-534.

Poli S and Schmidt M W $1995 \mathrm{H}_{2} \mathrm{O}$ transport and release in subduction zones: Experimental constraints on basaltic and andesitic systems; J. Geophys. Res. 100 22,29922,314 .

Poli S and Schmidt M W 1997 The high-pressure stability of hydrous phases in orogenic belts: An experimental approach to eclogite forming processes; Tectonophys. $\mathbf{2 7 3}$ 169-184.

Rast N 1965 Nucleation and growth of metamorphic minerals; Controls of Metamorphism, Edinburgh, pp. 73-102.

Ravna E J K 2000 The garnet-clinopyroxene $\mathrm{Fe}^{2+}-\mathrm{Mg}$ geothermometer: An updated calibration; J. Metamorph. Geol. 18 211-219.

Ravna E J K and Terry M P 2004 Geothermobarometry of UHP and HP eclogites and schists - an evaluation of equilibria among garnet-clinopyroxene-kyanite-phengitecoesite/quartz; J. Metamorph. Geol. 22(6) 579-592.

Ridley J 1984 Evidence of temperature dependent 'blueschist to eclogite' transformation in HP metamorphism of metabasic rocks; J. Petrol. 25 852-870.

Rossman G R 1996 Studies of $\mathrm{OH}$ in nominally anhydrous minerals; Phys. Chem. Min. 23 299-304.

Ruiz Cruz M D 2011 Origin of atoll garnet in schists from the Alpujárride Complex Central zone of the Betic Cordillera Spain: Implications on the P-T evolution; Mineral. Petrol. $101245-261$.

Sachan H K, Bodnar R J, Islam R and Law R D 1999 Exhumation history of eclogites from the Tso Morari crystalline complex in eastern Ladakh: Mineralogical and fluid inclusion constraints; J. Geol. Soc. India 53 181-190.

Sachan H K, Mukherjee B K, Ogasawara Y, Maruyama S, Pandey A A K M, Yoshioka N and Ishida H 2001 Discovery of coesite from Indian Himalaya: Consequences on Himalayan tectonics, paper presented at UltrahighPressure Minerals (UHPM) Workshop, Waseda Univ., Tokyo, Japan.

Sachan H K, Mukherjee B K, Ogasawara Y, Maruyama S, Ishida H, Muko A and Yoshioka N 2004 Discovery of coesite from Indus suture zone ISZ Ladakh India: Evidence for deep subduction; Eur. J. Mineral. 16 235-240.

Schlup M, Carter A, Cosca M and Steck A 2003 Exhumation history of eastern Ladakh revealed by ${ }^{40} \mathrm{Ar} /{ }^{39} \mathrm{Ar}$ and fission track ages: The Indus River-Tso Morari transect NW Himalaya; J. Geol. Soc. London 160 385-399.

Schmidt M and Poli S 1998 Experimentally based water budgets for dehydrating slabs and consequences for arc magma generation; EPSL 163 361-379.

Singh P, Saikia A, Pant N R and Verma P K 2013 Insights into the P-T evolution path of Tso Morari eclogites of the north-western Himalayas: Constraints on the geodynamic evolution of the region; J. Earth Syst. Sci. 122 677-698.

Smellie J A T 1974 Formation of atoll garnets from the aureole of the Ardara pluton Donegal Ireland; Mineral Mag. $39878-888$. 
Smith D C 1980 A tectonic melange of foreign eclogites and ultramafites in the Basal Gneiss Region, West Norway; Nature 287 366-368.

Smith D C 1981 A reappraisal of factual and mythical evidence concerning the metamorphic and tectonic evolution of eclogite-bearing terrain in the Caledonides; Terra Cognita 1 73-74.

Smith D C 1982 A review of the controversial eclogites in the Caledonides in First International Eclogite Conference; Terra Cognita 2317.

Smith D C 1984 Coesite in clinopyroxene in the Caledonides and its implications for geodynamics; Nature 310 641644.

Smith D C 1988 A review of the peculiar mineralogy of the Norwegian Coesite Eclogite Province; Elsevier Amsterdam 1206.

Smyth J R, Bell D R and Rossman G R 1991 Incorporation of hydroxyl in upper mantle clinopyroxenes; Nature 351 $732-734$.

Spear F S and Selverstone J 1983 Quantitative P-T paths from zoned minerals: Theory and tectonic applications; Contrib. Mineral. Petrol. 83 348-357.

Spencer D A, Tonarini S and Pognante U 1995 Geochemical and $\mathrm{Sr}-\mathrm{Nd}$ isotopic characterization of Higher Himalayan eclogites and associated metabasites; Eur. J. Mineral. 7 89-102.

Spiess R, Peruzzo L, Prior D J and Wheeler J 2001 Development of garnet porphyroblasts by multiple nucleation coalescence and boundary driven rotations; J. Metamorph. Geol. 19 269-290.

Steck A, Epard J L, Vannay J C, Hunziker J, Girard M, Morard A and Robyr M 1998 Geological transect across the Tso Morari and Spiti areas: The nappe structures of the Tethys Himalaya; Swiss J. Geosci. 91 103-122.

St-Onge M R, Rayner N, Palin R M, Searle M and Waters D J 2013 Integrated pressure-temperature-time constraints for the Tso Morari dome, northwest India: Implications for the burial and exhumation path of UHP units in the western Himalaya; J. Metamorph. Geol. 31 469-504.

Su W, You Z D, Cong D L, Ye K and Zhong Z Q 2002 Cluster of water molecules ingarnet from ultrahigh-pressure eclogite; Geology 30 611-614.

Thakur V C 1983 Deformation and metamorphism of the Tso Morari crystalline complex; In: Geology of the Indus Suture Zone of Ladakh (eds) Thakur V C and Sharma K K, Wadia Institute of Himalayan Geology, Dehradun, India, pp. 1-8.
Thompson A B 1992 Water in Earth's upper mantle; Nature 358 295-302.

Tischendorf G 1997 On Li bearing micas: Estimating Li from EPMA and an improved diagram for graphical representation; Mineral. Mag. 61 809-834.

Waters D J and Martin H N 1993 Geobarometry in phengite bearing eclogites; Terra Abstract 5 410-411.

Whitney D L 1996 Garnets as open systems during regional metamorphism; Geology 24 147-150.

Whitney D L 1991 Calcium depletion halos and Fe-Mn$\mathrm{Mg}$ zoning around faceted plagioclase inclusions in garnet from a high-grade pelitic gneiss; Am. Mineral. 76 493501.

Wilke F D H, O'Brien P J, Scmidt A and Ziemann M A 2015 Subduction peak and multi-stage exhumation metamorphism: Traces from one coesite-bearing eclogite Tso Morari, western Himalaya; Lithos 231 77-91.

Wilke F D H, O'Brien P J, Gerdes A, Timmerman M J, Sudo M and Khan A 2010 The multistage exhumation history of the Kaghan Valley UHP series NW Himalaya Pakistan from U-Pb and ${ }^{40} \mathrm{Ar} /{ }^{39} \mathrm{Ar}$ ages; Eur. J. Mineral. 22703 719 .

Williamson W C 1935 The composite gneiss and contaminated granodiorite of Glenn Shee Perthshire; Quart. J. Geol. Soc. London 91 382-419.

Withers A C, Wood B J and Carroll M R 1998 The OH content of pyrope at high pressure; Chem. Geol. 147 161171.

Xiao Y, Hoefs J, van den Kerkhof A M, Fiebig J and Zheng Y 2000 Fluid history of UHP metamorphism in Dabie Shan China: A fluid inclusion and oxygen isotope study on the coesite-bearing eclogite from Bixiling; Contrib. Mineral. Petrol. 139 1-16.

Xiao Y L, Hoefs J, van den Kerkhof A M and Li S G 2001 Geochemical constraints of the eclogite and granulite facies metamorphism as recognized in the Raobazhai complex from the North Dabie Shan China; J. Metamorph. Geol. 19 3-19.

Zheng Y F, Fu B, Gong B and Li L 2003 Stable isotope geochemistry of ultra high pressure metamorphic rocks from the Dabie-Sulu orogen in China: Implications for geodynamics and fluid regime; Earth Sci. Rev. 62 105161.

Zheng Y F, Fu B, Xiao Y, Li Y and Gong B 1999 Hydrogen and oxygen isotope evidence for fluid-rock interactions in the stages of pre- and post-UHP metamorphism in the Dabie Mountains; Lithos 46 677-693. 